\title{
Integrated Water Resource Assessment of Irrigation System of Haryana
}

\author{
Shiv Singh Rawat ${ }^{1,2^{*}}$, S. Lahari², A. K. Gosain ${ }^{2}$ \\ ${ }^{1}$ Irrigation and Water Resources Department, Gurugram, India \\ ${ }^{2}$ Indian Institute of Technology Delhi, New Delhi, India \\ Email:*ssrawat110@gmail.com
}

How to cite this paper: Rawat, S.S., Lahari, S. and Gosain, A.K. (2018) Integrated Water Resource Assessment of Irrigation System of Haryana. Agricultural Sciences, 9, 489-510.

https://doi.org/10.4236/as.2018.94034

Received: March 12, 2018

Accepted: April 27, 2018

Published: April 30, 2018

Copyright $\odot 2018$ by authors and Scientific Research Publishing Inc. This work is licensed under the Creative Commons Attribution International License (CC BY 4.0).

http://creativecommons.org/licenses/by/4.0/

\begin{abstract}
Agriculture is the major activity in the state of Haryana and large volume of water is required to meet the irrigation demands of the crops grown. But, there is limited water availability in the state. Haryana receives water from Yamuna River and Bhakra system. Sowmelt, rainfall and groundwater are main sources of water in the catchment. It is essential to integrate the manmade canal system with hydrological system. This paper focuses on integrated hydrological modeling framework to conceptualize the system and to assess the Water Resources of the state. Snowmelt and Rainfall runoff modeling using GR4JSG model were combined to model the inflows to the irrigation system of Haryana. Irrigator canal model of eWater Source has been used to generate water demands from crops grown. The water balance and water use efficiency have been worked out for each district of Haryana. The hydro climate input data, stream flows, crop data and soil data have been used in the study. The flows modeled at Tuini (P), Yashwant Nagar, Bausan, Haripur, Poanta and HKB sites were compared with the observed flows. The objective function of NSE Daily and log Flow duration was used for model calibration and validation at various locations up to Mathura, the outlet of the study area. The value of the objective function at Mathura was 0.54 , a fairly good value. The results of the Irrigator canal model have shown that all the Inflows, Outflows and the Utilizations of water have been properly balanced for each district. The water use efficiency of districts varies from $27 \%$ to $59 \%$. The overall water use efficiency for Haryana canal system has been calculated as $39 \%$. This is low value indicating excess water is being extracted to meet the water demands.
\end{abstract}

\section{Keywords}

Hydrological Modeling, GR4JSG Model, GR4J Model, MODIS Snow Cover, Irrigator Canal Model, eWater Source, Water Balance and water Use Efficiency 


\section{Introduction}

Haryana state uses majority of water resources in agriculture sector. The state receives surface water from Yamuna, Sutlej, Ravi and Beas rivers as per various interstate water sharing agreements. The state does not have any perennial river. The Western Jamuna Canal (WJC) system and Bhakra system are the two main canal systems irrigating 2.97 million hectare area. The intensity of canal irrigation is not uniform throughout the state due to highly skewed distribution of canal water in different commands. Some areas are getting more water and the others getting less because of capacity and other constraints. The water use efficiency in the state is $60 \%$ [1] and for WJC system the water use efficiency is $36 \%$ to $43 \%$ [2]. The present water availability in the state is 14 Million Acre Feet (MAF) or 17 Billion Cubic Meter (BCM) and projected water demands is 36 MAF (45 BCM) in 2045 [1]. There is a huge gap between demand and supply of water resources. Ground Water (GW) has been over exploited that have caused depletion of water table and deterioration of quality of water. The ground water has declined in parts of the state and also increased in other parts of the WJC command [3]. The sweet water is going down and saline water is rising up. The per capita freshwater availability is declining and there is rapid deterioration of the available resources in the state and low flows in Yamuna causing environmental issues.

Snowmelt is a major contributor to the Hydrology of Yamuna and other Himalayan Rivers. Snow melt contributes about 30\% - 50\% of annual stream flow in Himalayan Rivers [4]. The flows in the Yamuna River are higher from June to September due to monsoon rainfall and snowmelts in the upper catchment. But during non monsoon the water in river is due to snowmelt and base flow. The variation in rainfall has visible effect on the flow. There is temporal as well as spatial variability in the amount of water supplied due to lack of storage across Yamuna. At HKB, the average high flow is 7079 cumecs and minimum flow is 70 cumecs [2].

Snow melt water, surface water of canals/streams/drainage system, ground water and crop water demands are interconnected and play an important role in the study area. It is essential to integrate the manmade canal system with hydrological system. Hence, there is an urgent need of an integrated hydrological modeling framework to conceptualize the system and to assess the Water Resources of the state. The system has been conceived to have the catchment models and schematic canal model. The hydrological modeling (snow and rainfall runoff) of the river basin is the usual water resource assessment methodology by means of considering basin as a natural unit and using land uses and hydrological response units. The methodology used in this study has been depicted in Figure 1. Rainfall runoff model with snow melt from hilly areas are conceptualized and the water flows are diverted to canal system of Haryana through WJC system. The flows are utilized to meet the crop water demand generated by Irrigator canal model. 


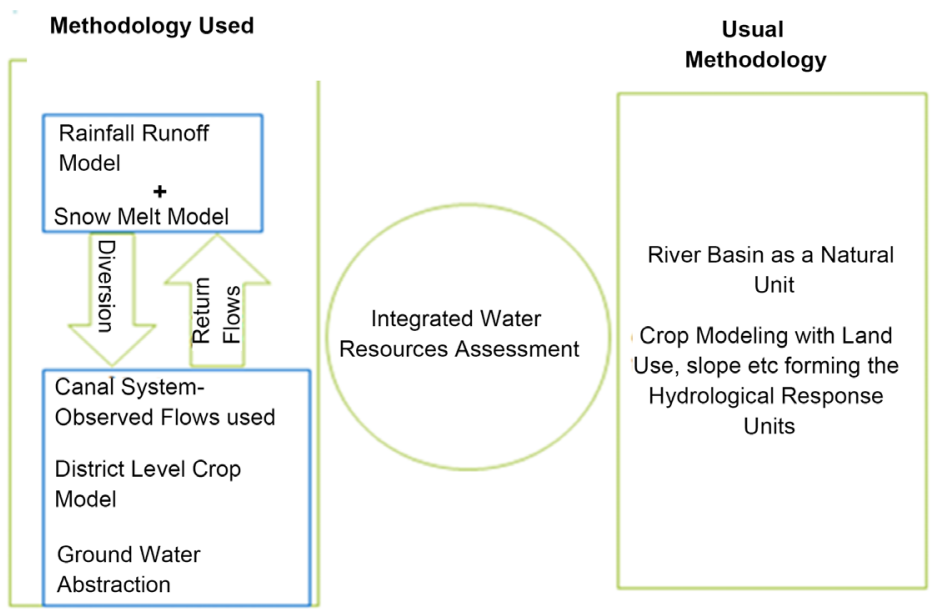

Figure 1. Concept of the integrated water resources assessment model.

\section{Study Area}

The present study covers the Yamuna River Basin up to Mathura and adjacent Irrigation Canal System of Haryana (Figure 2). The outlet of the study area is at Mathura on Yamuna. Yamuna originates from the Yamunotri Glacier near Bander Punch peak $\left(38^{\circ} 59^{\prime} \mathrm{N}, 78^{\circ} 27^{\prime} \mathrm{E}\right)$ in the Mussourie range of lower Himalayas, at an elevation of 6320 meter above mean sea level (amsl) in Uttarkashi District of Uttarakhand. The study is focused on an area of $60,557 \mathrm{~km}^{2}$ including $11,397.78 \mathrm{~km}^{2}$ hilly area upstream of HKB and $27,740 \mathrm{~km}^{2}$ irrigation command area of the state. The elevation ranges from $150 \mathrm{~m}$ amsl to $6253 \mathrm{~m}$ amsl in the study area. The river water at $\mathrm{HKB}$ is diverted into Western Jamuna Canal (WJC) and Eastern Jamuna Canal (EJC) to supply water for irrigation and drinking purposes to the States of Haryana and Uttar Pradesh respectively and also drinking water supply of Delhi.

Yamuna basin is a heterogeneous and has high spatial variation of rain fall varying from $200 \mathrm{~mm}$ to $2350 \mathrm{~mm}$. The annual average rainfall is $906 \mathrm{~mm}$. The rainfall in the study area is from South West monsoon and major part of rain fall is received between June to September. The rainfall is scanty in winter. However, temperature and rainfall vary with altitude. The mean maximum and minimum temperature vary between $24^{\circ} \mathrm{C}$ to $45^{\circ} \mathrm{C}$ and $-1^{\circ} \mathrm{C}$ to $11^{\circ} \mathrm{C}$ respectively. The annual rainfall is much lower i.e. about $1000 \mathrm{~mm}$ in the foot hills to less than 600 $\mathrm{mm}$ in Haryana and Delhi. Haryana is mostly arid or semiarid. There is limited rainfall in Haryana ranging from $300 \mathrm{~mm}$ in the South West to $1100 \mathrm{~mm}$ in the North East. Average annual rainfall is $573 \mathrm{~mm}$. The soils in the Yamuna basin are predominately alluvial.

\section{Methods and Materials}

This section describes the GR4JSG model for snow melt and rainfall runoff, the Irrigator Demand model for generation of crop water demand and the input data used in the study. 


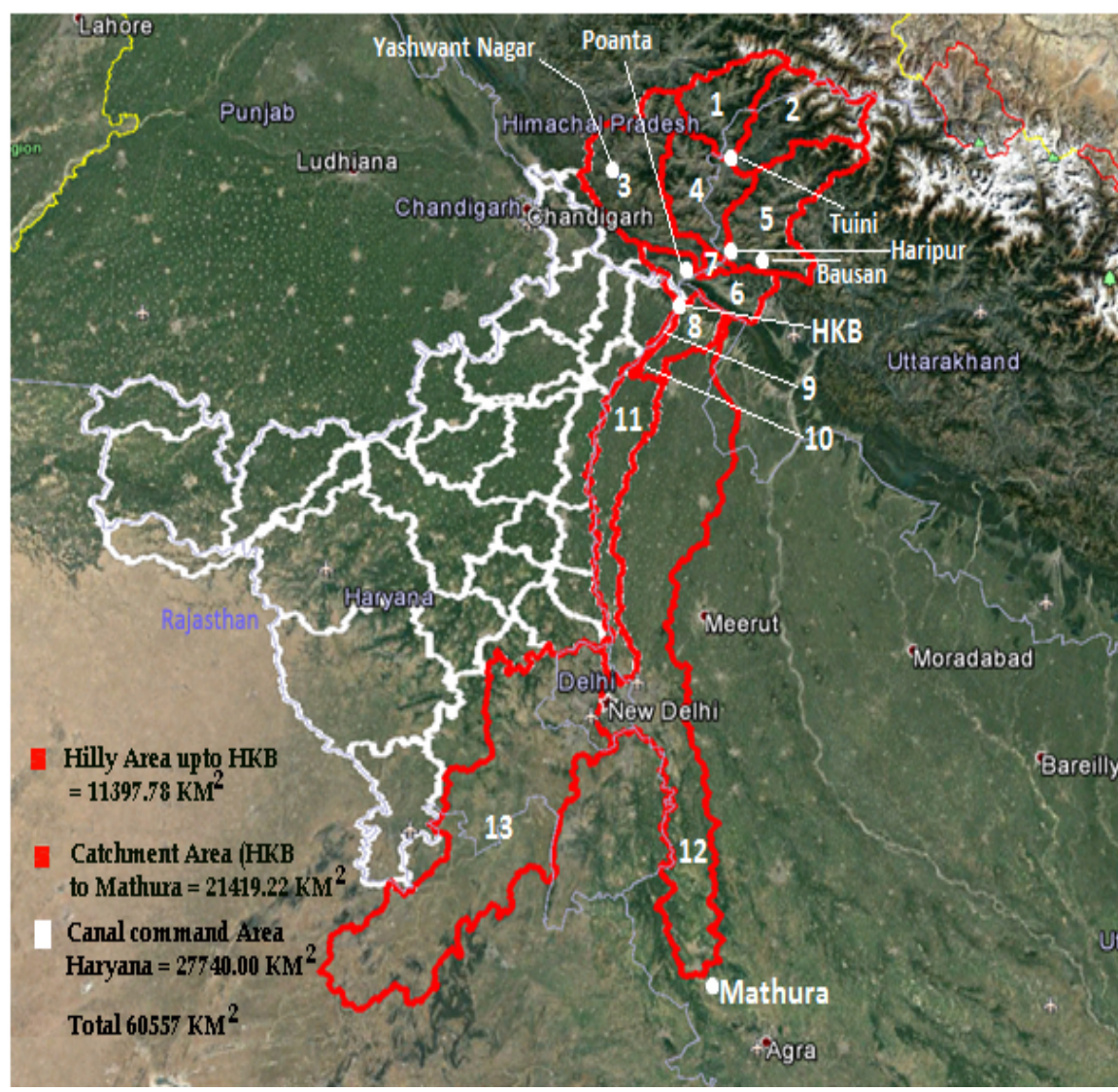

Figure 2. Yamuna basin up to Mathura and adjoining Haryana area (Source Google Map).

\subsection{Model Description}

\subsubsection{Description of GR4JSG Model}

GR4JSG model developed by [5] has been used for rainfall runoff, snowmelt and glacial melt simulation. GR4JSG model is based on GR4J model [6]. The degree day factor has been use to describe the snow and ice melt processes [7]. The GR4JSG model is used within the eWater Source modeling framework [8]. The conceptual structure of the model is shown in Figure 3, with the original GR4J model developed by [6] and it is shown on the left side and the additional snow and ice stores shown on the right side. The GR4J model is a daily lumped rainfall-runoff model with four parameters $\left(\mathrm{x}_{1}, \mathrm{x}_{2}, \mathrm{x}_{3}\right.$ and $\left.\mathrm{x}_{4}\right)$. GR4J consists of two main stores: the production store and the routing store as shown in the conceptual structure of Figure 3. The time series inputs to the model are rainfall depth (P) in $\mathrm{mm} /$ day and potential evapotranspiration (E) in $\mathrm{mm} /$ day.

The parameter $\mathrm{x}_{1}$ controls the size of the production store $(\mathrm{mm}), \mathrm{x}_{2}$ controls the flux to groundwater ( $\mathrm{mm} /$ day), $\mathrm{x}_{3}$ controls the size of the routing store $(\mathrm{mm})$ and $\mathrm{x}_{4}$ controls the recession of the unit hydrograph (days).

The snow and glacier processes are represented in GR4JSG model by two conceptual stores for snow and ice. The temperature is used to decide if precipitation is rainfall or snow. The snow accumulation and melt are represented by snow store and glacier melt processes are represented by the ice store. Snow is 


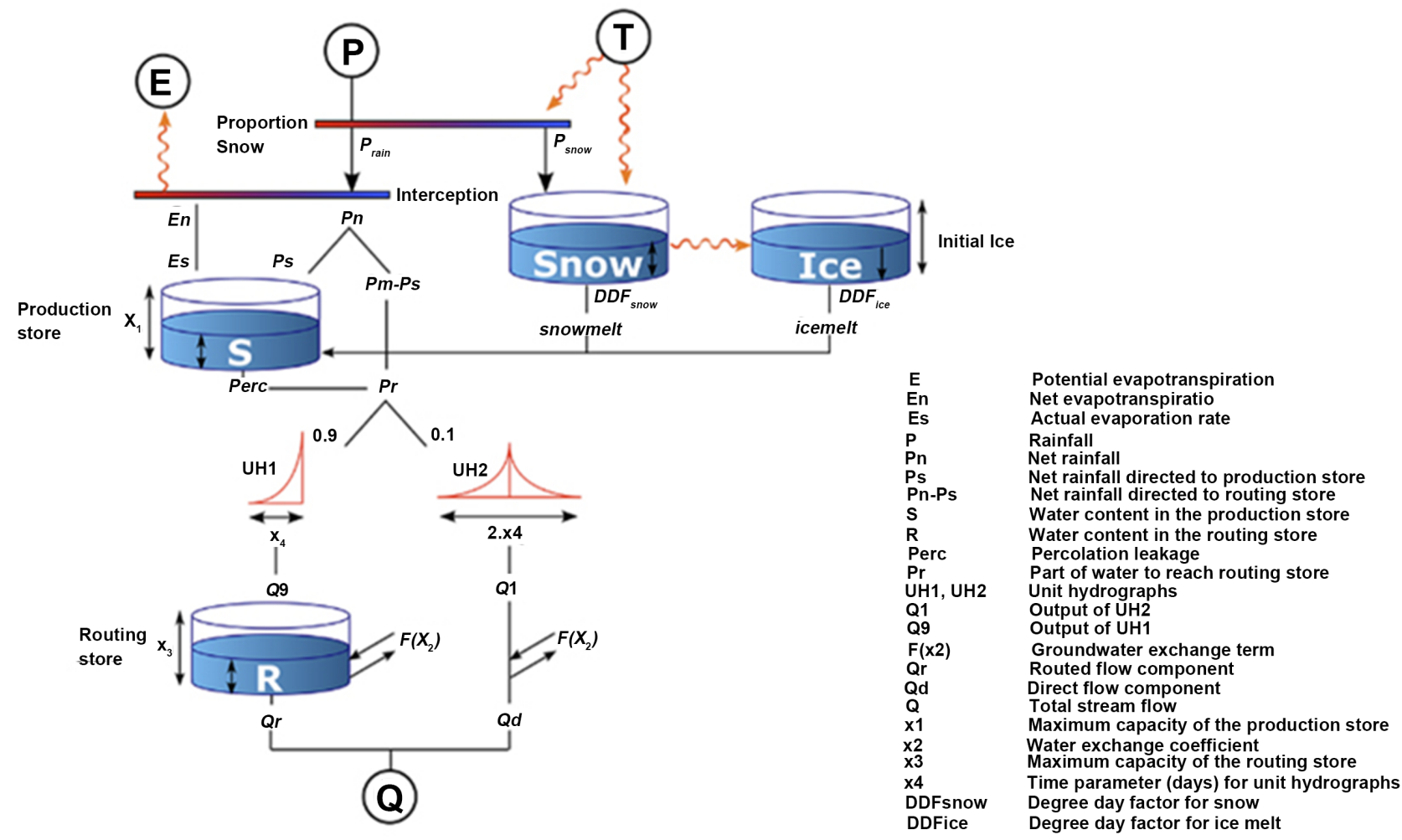

Figure 3. Conceptual structure of the GR4JSG (GR4J + Snow and Glacier) model [5].

melted prior to the glacier melting and it is accumulated in the snow store. The snowmelt obtained from the snow area infiltrates the soil and enters the production store. Afterwards it is treated as though it was rainfall. The production store gets contributions from snowmelt and rainfall. The amount of snowmelt contribution to the runoff is calculated separately. For more details on GR4J and GR4JSG models please refer to [5] and [6].

\subsubsection{Irrigator Demand Model (Crop Model)}

A supply point and water use nodes have been used to model the water use in Source platform [9]. The demand models are provided by the water user nodes and that can be configured to represent irrigation demand. Irrigator is applied through a water user node and connected to at least one supply point node to provide water to meet with the irrigation demand. Irrigator maintains a daily water balance for each cropping area during its planting season so as to calculate the daily soil water deficit and irrigation requirement. A water balance of the fallow crop is also used to initialize the soil moisture store when new crops are grown. The fallow cropping area does not order or receive irrigation water. The daily water balance includes effective rainfall, irrigation, runoff, evapotranspiration and deep percolation that affect changes in soil water storage. The irrigator uses the method described in FAO 56 [10] to represent the daily crop water balance. Irrigator is conceptualized to represent at irrigation district scale rather than an individual irrigator. The total requirement for the district is calculated 
by summing each of the individual cropping area requirements. The district requirement is then adjusted to allow for any district supply escapes and losses associated with delivering water to the district. For more details refer to FAO 56 [10] [11] [12].

\subsection{Data Collection}

\subsubsection{Basin Area and Elevations}

Shuttle Radar Topography Mission (SRTM) Digital Elevation Model (DEM) has been used for delineation of the study area watershed [http://srtm.csi.cgiar.org/]. The horizontal resolution is $90 \times 90 \mathrm{~m}$ of used in this study. The projections are WGS 1984, 43N. ArcMap 10.2 is used to extract sub catchments and to calculate the area and the area-elevation distribution of the basin. The catchment has been divided into 13 sub catchments, including 7 sub catchments in hilly areas. The elevation of the study area varies from $150 \mathrm{~m}$ to $6253 \mathrm{~m}$. The basin is subdivided in 11 elevation zones/bands each with a vertical difference of $600 \mathrm{~m}$ in hilly areas (Table 1). Each elevation zone acts as a functional unit. Source conceptualizes catchment as a combination of functional units [13]. A functional unit (FU) is a part of catchment that functions in a similar way for hydrological processes, and which may be defined by different climate, land use, soil type or runoff processes.

Functional unit may have different model parameters or inputs to another FU in the catchment. For this study, temperature, precipitation and evapotranspiration were used for each FU. The runoff at all 11 FUs from GR4JSG models was summed to calculate runoff at a point. The areas enclosed by various elevation contours can be determined with Arc Map 10.2 spatial analyst tool by making use of the zone boundaries and other selected contours in the basin. The mean hypsometric elevation of each zone is used as the elevation to which base station temperatures are extrapolated for the calculation of number of zonal degree-days (Table 1).

\subsubsection{Hydro Meteorological Input data}

The time series data of daily precipitation, daily minimum and maximum temperatures, potential evapotranspiration (PET), stream flow and monthly snow cover has been used to calibrate and validate the model. The data of Indian Meteorology department (IMD) and Central Water Commission (CWC) has been used in this study.

\section{1) Temperature}

The IMD gridded maximum and minimum temperatures data from year 1995 to 2013 has been used in this study. As temperature varies with elevation, so, temperature lapse rate has been used to estimate the temperature at the unmeasured locations. The temperature lapse rate has been taken from the literature of nearby basins of Himalayan region due to lack of historical data of the temperature lapse rate in the Yamuna basin. The annual lapse rates $0.51^{\circ} \mathrm{C} / 100 \mathrm{~m}$ to $0.68^{\circ} \mathrm{C} / 100 \mathrm{~m}$ have been found by [14] for Snowmelt Runoff Model to Tamor catchment. The seasonal lapse rates of $0.55^{\circ} \mathrm{C} / 100 \mathrm{~m}$ for monsoon (June to 
Table 1. Area of elevation zones and hypsometric mean elevations.

\begin{tabular}{ccccc}
\hline $\begin{array}{c}\text { Elevation } \\
\text { Zone }\end{array}$ & $\begin{array}{c}\text { Elevation } \\
\text { Range }(\mathrm{m})\end{array}$ & Zonal Area $\left(\mathrm{Km}^{2}\right)$ & $\begin{array}{c}\text { Zonal Area as \%age of } \\
\text { Total study area }\end{array}$ & $\begin{array}{c}\text { Hypsometric Mean } \\
\text { Elevation }(\mathrm{m})\end{array}$ \\
\hline 1 & $327-600$ & 824.06 & 7.24 & 489.48 \\
2 & $601-1200$ & 1424.21 & 12.52 & 911.04 \\
3 & $1201-1800$ & 2896.85 & 25.46 & 1521.15 \\
4 & $1801-2400$ & 2825.35 & 24.83 & 2083.16 \\
5 & $2401-3000$ & 1539.59 & 13.53 & 2656.64 \\
6 & $3001-3600$ & 745.60 & 6.55 & 3274.44 \\
7 & $3601-4200$ & 484.82 & 4.26 & 3892.18 \\
8 & $4201-4800$ & 439.89 & 3.87 & 4481.03 \\
9 & $4801-5400$ & 165.44 & 1.45 & 5042.05 \\
10 & $5401-6000$ & 31.61 & 0.28 & 5576.16 \\
11 & $6001-6253$ & 0.49 & 0.01 & 6099.23 \\
\hline
\end{tabular}

September) and $0.6^{\circ} \mathrm{C} / 100 \mathrm{~m}$ for the dry season (October to May) has been derived by [15] in Dudh Koshi catchment. The lapse rate from $0.65^{\circ} \mathrm{C}$ and $0.69^{\circ} \mathrm{C}$ per $100 \mathrm{~m}$ were found by [16] in Beas basin during the years 1998 and 1999 respectively. The temperature lapse rate $0.65^{\circ} \mathrm{C} / 100 \mathrm{~m}$ was used by [17] in Alakhnanda and Bhagirathi Basin of Ganga basin. A temperature lapse rate of $-0.65^{\circ} \mathrm{C}$ per $100 \mathrm{~m}$ has been used in the study.

\section{2) Precipitation}

The IMD gridded precipitation data from year 1995 to 2013 has been used in this study. It is difficult to extrapolate precipitation in mountainous watersheds due to lack of weather stations in the watershed and local factors. The topography strongly influences the spatial distribution. However; the rainfall scaling factor of $10 \mathrm{~mm} / \mathrm{km}$ has been used from literature.

\section{3) Potential evapotranspiration}

The global data from the http://hydrology.princeton.edu/data.measures_pet.php from year 1995-2013 has been used. The PET is corrected using PET decay rate of $-0.0005 \mathrm{~mm} / 1000 \mathrm{~m}$ for Himalayan area [18].

\section{4) Discharge Data}

The Discharge data of Central Water Commission of India (CWC) is used for CWC sites at Tuini (Pabra), Yashwantnagar, Bausan, Haripur, Poanta and Mathura. The flow data of various canals from year 1995-2015 has been collected from Haryana Irrigation and Water Resources Department.

\subsubsection{Crop and Soil Data}

Wheat, Barley, Rabi oil seeds, Gram and Sun Flower (Rabi crops) and Rice, Bajra, Maize, Cotton, Jowar and Sugar Cane (Kharif crops) are the main crops grown in Haryana state. The data of crop areas, crop factors, root zone depth, 
depletion factor, planting and harvesting dates, target soil depletion, field capacity, permanent wilting point, soil moisture capacity, soil types and ground water extractions etc have been obtained from Haryana Agriculture department, reference [1] [10] and Indian Agricultural Research Institute (IARI), New Delhi.

\section{Results and Discussion}

\subsection{Model Calibrationand Validation}

The split-sample technique has been used in the study. The model has been calibrated from January 1, 1995 to December 31, 2005 and then validated from period January 1, 2006 to December 31, 2013. A warm-up period of one year (January1, 1995 to December 31, 1995) was sufficient to remove any trends in the snow store states. The model was calibrated using calibration tool in the Source. The calibration was done using the "Shuffled Complex Evolution then "Rosenbrock" option [11]. The objective function used is NSE Daily and log flow durations. NSE is Nash Sutcliffe Efficiency [19].

The model has been calibrated at six different CWC Discharge sites. The Model is first calibrated at Tuini Pabra which covers sub catchment 1 and 2 . Then it is calibrated at Yashwantnagar site for sub catchment 3. Next calibration site is Bausan for sub catchment no. 5, Haripur for Sub catchment no. 1, 2, 3, 4, Poanta sahib site for sub catchment no. 1, 2, 3, 4, 5 and 7. The model is then calibrated at $\mathrm{HKB}$, the outlet of the study area covering all upstream sub catchments from 1 to 7 . The results of Calibration and validation showing NSE daily and $\log$ flow duration and values of eight Metaparameters are tabulated in Table 2. During the calibration period the Mataparameters have been modified so as to improve the fit between the model values and the observed values. The objective function of NSE Daily \& $\log$ Flow duration have been found between 0.69 to 0.85 for calibration and between 0.60 to 0.73 for validation period and the values are fairly good.

\subsection{Water Balance at District Level}

After running of both GR4JSG model and GR4J model, the Irrigator canal model (Crop model) is run. Then, water balance of all the districts in Haryana has been worked out. Water balance is evaluation of all the water inflows, outflows and utilizations of all canals in the district. The water balance of Karnal District is being explained in this paper to show how the water balance of each district has been worked out both for calibration and validation periods (Figure 4).

The water is supplied to Karnal district by five canals: Chautang feeder, Offtakes of WJC-MB, Nardak Gogripur offtakes of NBK link, other offtakes of NBK and Goli distributory to meet the irrigation water demands generated by the five water user node on each of the above canals. The total inflow volume in Karnal district is the sum of downstream flow volumes of all the four inflow links (Indri_1 link, Default link 788, NBK link 53 and the Default link 103). The total outflow volume in Karnal district is the sum of downstream flow volumes of 
Table 2. Calibration and validation results of at 6 CWC stations up to HKB.

\begin{tabular}{|c|c|c|c|c|c|c|c|c|c|c|c|}
\hline Station & Subcatchments & $\begin{array}{c}\text { NSE Daily \& } \\
\text { log Flow } \\
\text { Duration } \\
\text { (Calibration) }\end{array}$ & $\begin{array}{c}\text { NSE Daily \& } \\
\text { log Flow } \\
\text { Duration } \\
\text { (Validation }\end{array}$ & DDFs & $\begin{array}{c}\text { Melt } \\
\text { Threshold }\end{array}$ & $\begin{array}{l}\text { Taccum } \\
\text { Threshold }\end{array}$ & Tfraction & $\mathrm{x}_{1}$ & $\mathrm{x}_{2}$ & $\mathrm{x}_{3}$ & $\mathrm{x}_{4}$ \\
\hline Tuini (P) & 1,2 & 0.79 & 0.72 & 2.13 & 3 & -0.27 & 0.23 & 1500 & -10 & 258.8 & 0.99 \\
\hline $\begin{array}{c}\text { Yashwant } \\
\text { Nagar }\end{array}$ & 3 & 0.71 & 0.60 & 0 & -3 & -3 & 1 & 66.34 & -4.55 & 500 & 0.74 \\
\hline Bausan & 5 & 0.77 & 0.65 & 3.44 & -0.95 & -0.97 & 0.87 & 1500 & -5.14 & 228.3 & 0.85 \\
\hline Haripur & $1,2,3,4$ & 0.69 & 0.61 & 0 & -1.76 & 1.12 & 0.12 & 179.01 & -5.81 & 69.38 & 1.17 \\
\hline Poanta & $1,2,3,4,5,7$ & 0.85 & 0.73 & 0 & -3 & 2.93 & 0.41 & 30.02 & -9.41 & 191.1 & 0.96 \\
\hline $\mathrm{HKB}$ & $1,2,3,4,5,6,7$ & 0.74 & 0.61 & 2.02 & 3 & -1.05 & 0.53 & 622.71 & 2.09 & 45.21 & 1.28 \\
\hline
\end{tabular}

\section{Calibration - District Karnal}

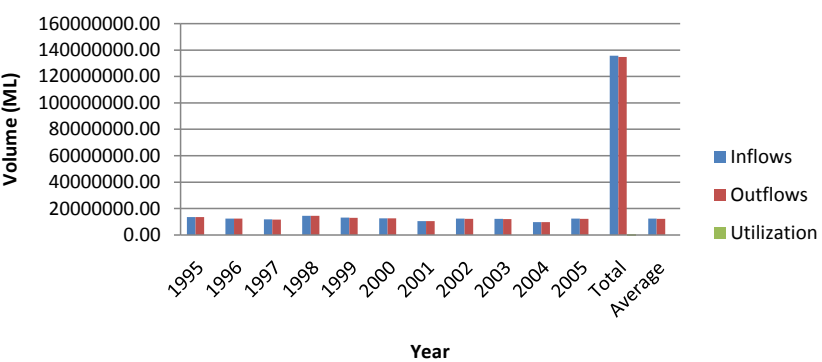

(a)

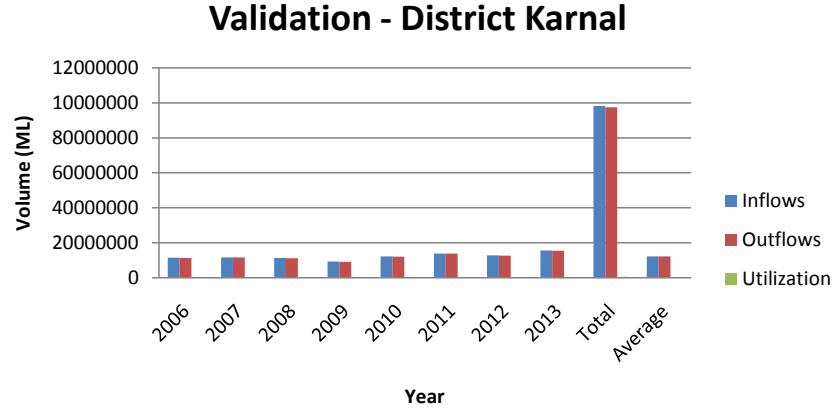

(b)

Figure 4. Water balance of Karnal district (Calibration and Validation).

all the four outflow links (Indri_2 link, WJC_MB upstream SYL link, NBK link to WJC-MB and the Default link 104) and also the downstream flow volume of all the above five supply points. It is important to add the downstream flow volume from supply points to the outflow. The reason we added the downstream flow volume from supply point to outflow is that all the water that comes to supply points is not extracted by the water user, so we need to add the downstream flow volume at the supply point to outflows. For Irrigator water user, the ordered water is calculated based on forecast rainfall and evaporation, so it is actually a forecast order. Water that will be released from upstream to meet the demand of the water user is based on this forecast order.

But the extracted volume is based on real order which is re-calculated based on current time step's rainfall and evaporation. So, it could happen that water user orders more than actually needed, if it rains more and evaporates less on that time step. The total volume of water utilizations in Karnal district is the sum of the extracted volume of all the five supply points. The water balance of Karnal district has been worked to satisfy the following equation:

$$
\text { Total Inflows }-(\text { Total Outflows }+ \text { Total Utilizations })=0
$$

The total inflow volumes in Karnal district during Calibration period is $135,634,745 \mathrm{ML}$ and 98,151,772 ML for validation period. The total outflow volumes in Karnal district during Calibration period is 134,745,035 ML and 
97,486,167 ML for validation period. The total volume of water utilizations in Karnal district during Calibration period is $889,710.3 \mathrm{ML}$ and 665,604.9 ML for validation period (Figure 4 and Table 3 ). The average inflows, outflows and utilizations in Karnal District for the period 1995-2013 come out to be 12,304,553.53 ML, 12,222,694.84 ML and 81,858.69 ML respectively.

It has been found that the above water balance equation has been properly satisfied for Karnal district. It proves that irrigator canal model has been properly set up. Similarly, the water balance has been worked out for the remaining districts of Haryana for calibration and validation period. The water balance of all districts of Haryana state has been shown in (Figure 5 and Figure 6). For all districts the water balance equation is satisfied. It shows that the crop model has been properly set up. The overall water balance of Haryana canal system for calibration, validation period and also overall period 1995-2013 is shown in Table 4.

Table 3. Water balance of Karnal district (Calibration and Validation).

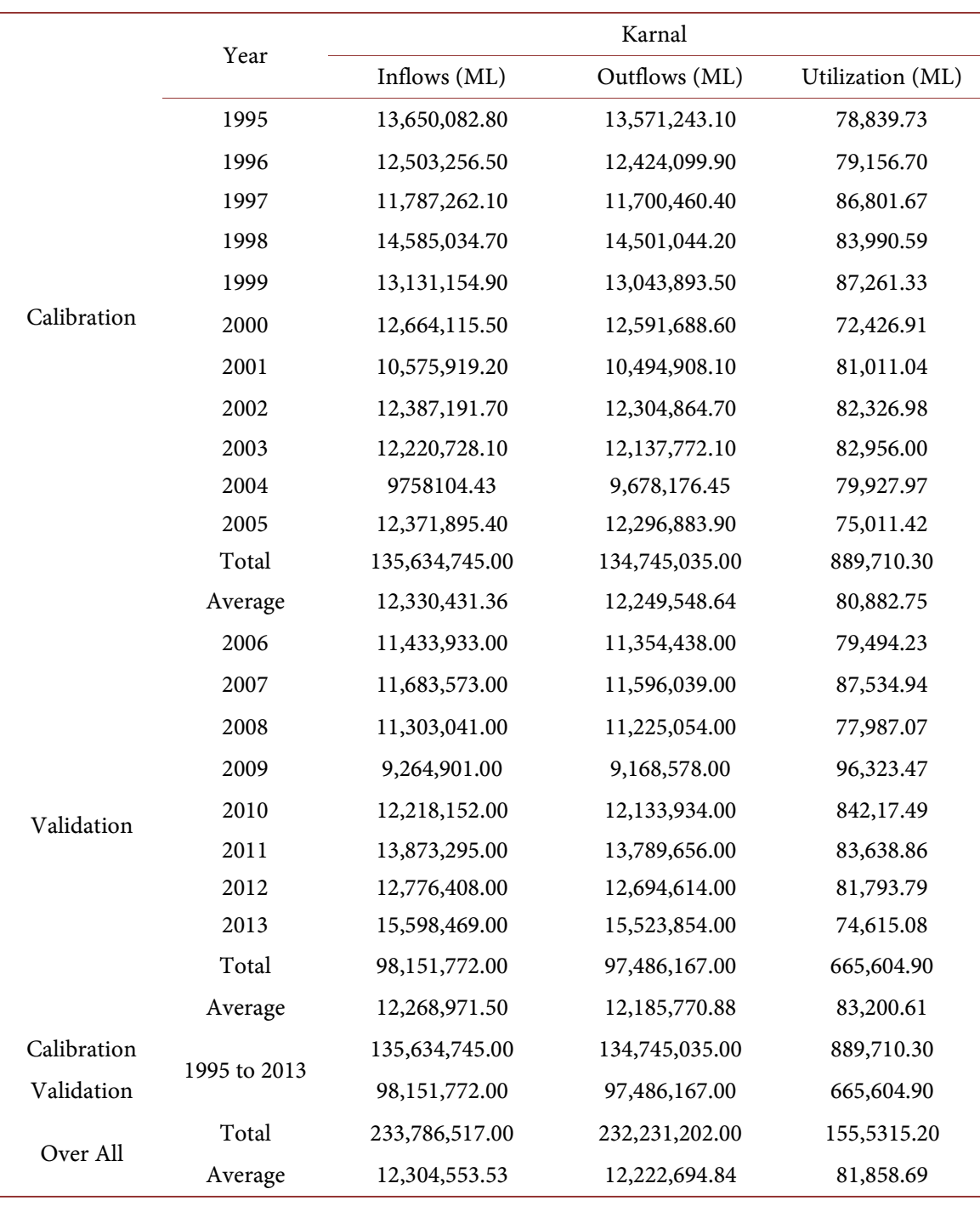


Table 4. Over all water balance of Haryana (Calibration and Validation).

\begin{tabular}{|c|c|c|c|c|}
\hline & & & ver All (Haryana) & \\
\hline & & Inflows (ML) & Outflows (ML) & Utilization (ML) \\
\hline & 1995 & $78,578,181.96$ & $73,288,568.43$ & $5,289,615.91$ \\
\hline & 1996 & $82,477,596.39$ & $76,995,340.00$ & $5,482,260.14$ \\
\hline & 1997 & $55,385,827.96$ & $50,139,191.95$ & $5,246,633.76$ \\
\hline & 1998 & $63,228,317.71$ & $57,892,341.90$ & $5,335,977.16$ \\
\hline & 1999 & $62,155,777.11$ & $56,209,651.05$ & $5,946,123.87$ \\
\hline Calibration & 2000 & $79,732,588.56$ & $74,127,687.31$ & $5,604,900.32$ \\
\hline & 2001 & $73,999,898.74$ & $68,864,929.73$ & $5,134,968.78$ \\
\hline & 2002 & $58,737,588.40$ & $52,969,392.81$ & $5,768,195.37$ \\
\hline & 2003 & $57,746,419.89$ & $52,652,734.21$ & $5,093,684.16$ \\
\hline & 2004 & $48,357,879.30$ & $43,173,571.16$ & $5,184,308.25$ \\
\hline & 2005 & $56,897,024.27$ & $51,509,832.89$ & $5,387,191.00$ \\
\hline & Total & $717,297,099.16$ & $657,823,239.99$ & $59,473,858.00$ \\
\hline & Average & $65,208,827.20$ & 59802112.73 & $5,406,714.36$ \\
\hline & 2006 & $57,377,791.30$ & $52,185,367.90$ & $5,192,423.30$ \\
\hline & 2007 & $57,683,469.50$ & $52,020,881.10$ & $5,662,591.64$ \\
\hline & 2008 & $55,706,407.70$ & $50,066,382.90$ & $5,640,025.70$ \\
\hline & 2009 & $50,174,318.40$ & 44801155.70 & $5,373,161.03$ \\
\hline & 2010 & $56,461,121.40$ & $50,494,020.20$ & $5,967,100.28$ \\
\hline Validation & 2011 & $64,428,724.90$ & $59,149,073.00$ & $5,279,651.20$ \\
\hline & 2012 & $60,901,019.00$ & $55,472,994.90$ & $5,428,024.89$ \\
\hline & 2013 & $68,481,779.80$ & 62968749.10 & $5,513,030.74$ \\
\hline & Total & $471,214,629.00$ & 427158623.00 & $44,056,006.46$ \\
\hline & Average & $58,901,828.63$ & $53,394,827.88$ & $5,507,000.81$ \\
\hline Calibration & 1995 to 2013 & $717,297,099.16$ & $657,823,239.99$ & $59,473,858.00$ \\
\hline Validation & & $471,214,629.00$ & $427,158,623.00$ & 44056006.46 \\
\hline$m 1$ & Total & $1,188,511,728.16$ & $1,084,981,862.99$ & $103,529,864.46$ \\
\hline & Average & $62,553,248.85$ & $57,104,308.58$ & $5,448,940.23$ \\
\hline
\end{tabular}

The average water utilization in Haryana for calibration period (1995-2013) is 5,406,714.36 ML and for validation period (2006-2013) the utilization are $5,507,000.81 \mathrm{ML}$. The average annual utilization for entire period (1995-2013) is $5,448,940.23 \mathrm{ML}$.

\subsection{Ground Water Fluctuations}

The ground water levels are observed in June and October every year. The fluctuations in ground water level (depth) for the year 1974 to 2010 both for June and October have been shown in Table 5. The overall fluctuations of Haryana state have been shown in Figure 7. 


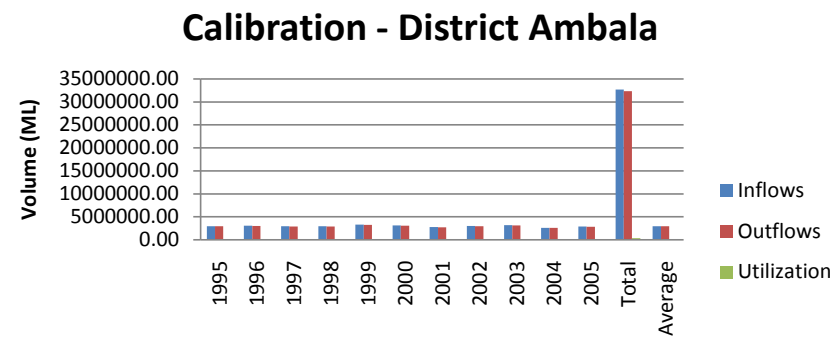

Year

(a)

\section{Calibration - District Faridabad}

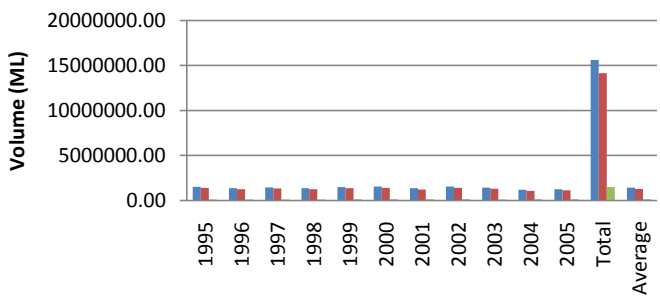

Year

(b)

\section{Calibration - District Jhajjar}

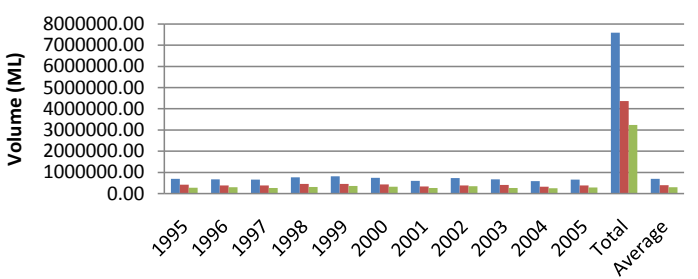

Year

(d)

\section{Calibration - District Kurukshetra}

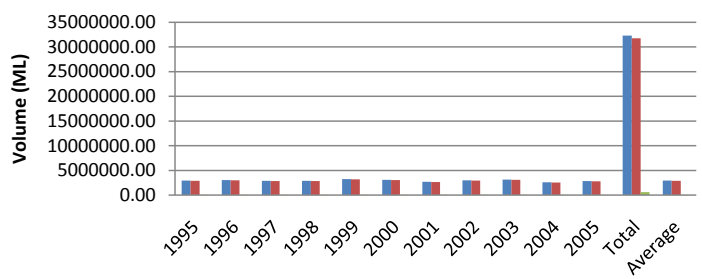

Year

(f)

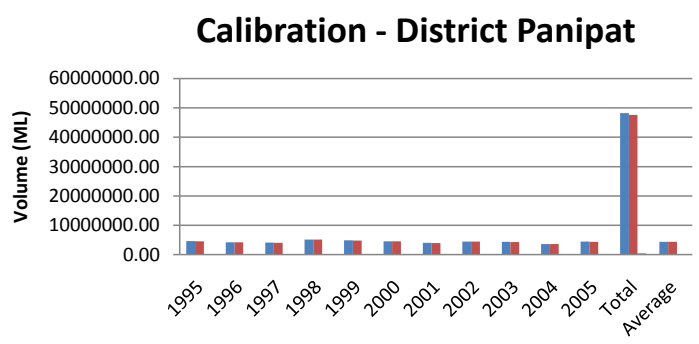

Year

(h)

\section{Calibration - District Gurugram}

Inflows

- Outflows Utilization

Inflows - Outflows Utilization - Outflows Utilization - Outflows - Utilization

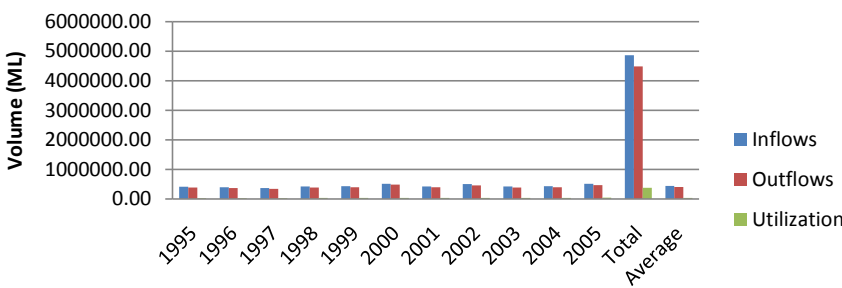
Year

(c)

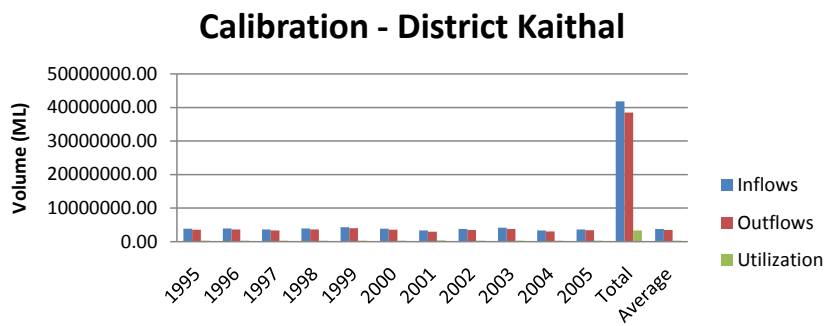

Year

(e)

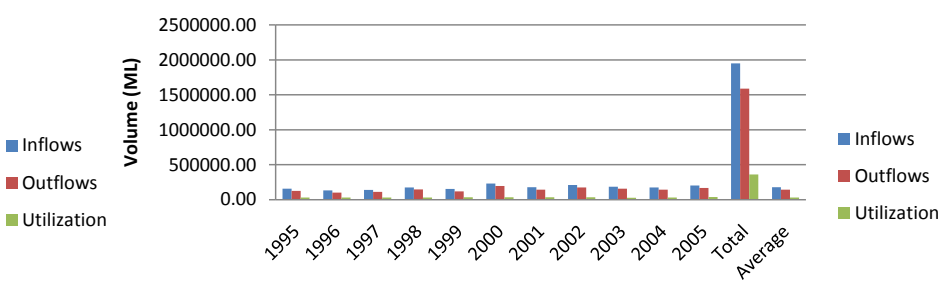

(g)

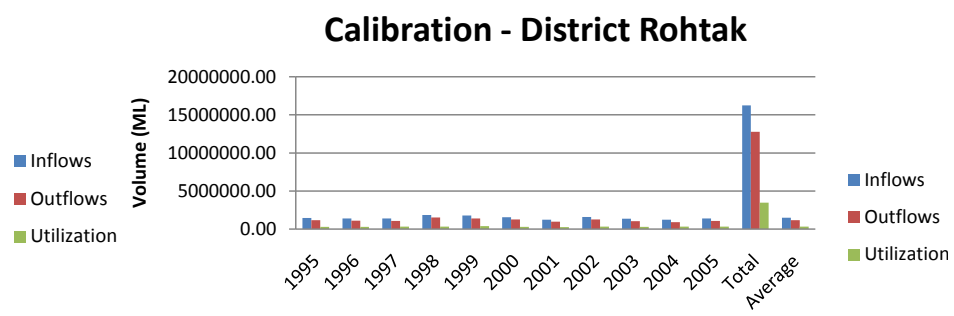

(i) 


\section{Calibration - District Sonepat}

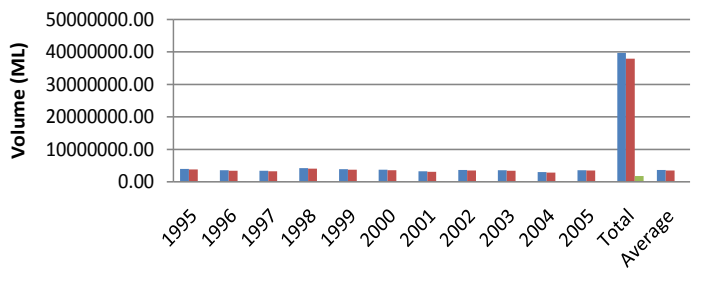

Year

(j)

\section{Calibration - District Fatehabad}

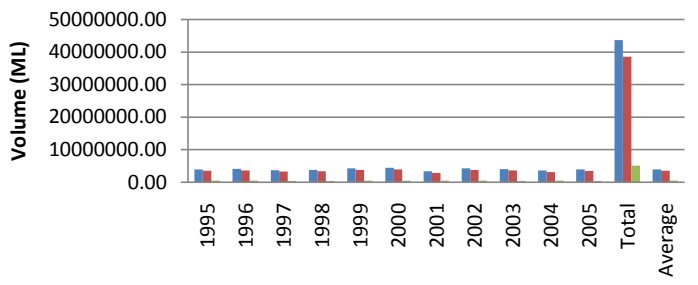

Year

(l)

\section{Calibration - District Jind}

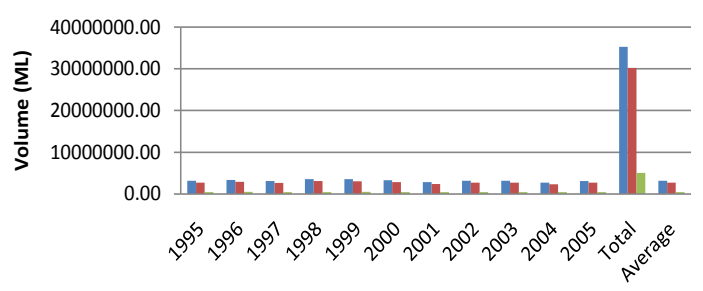

Year

(n)

\section{Calibration - District Mahendergarh}

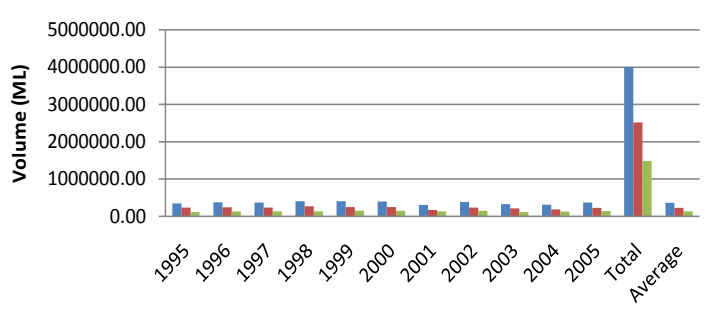

Year

(p)

\section{Calibration - District Rewari}

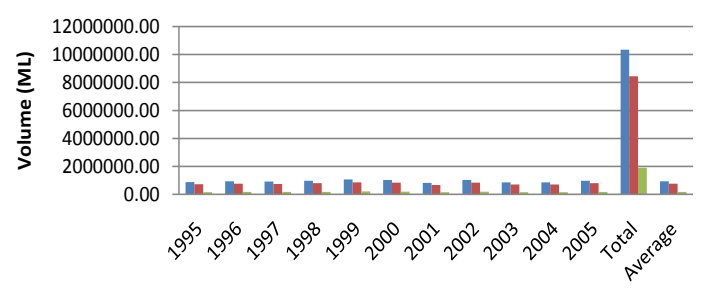

Year

(r)

\section{Calibration - District Bhiwani}
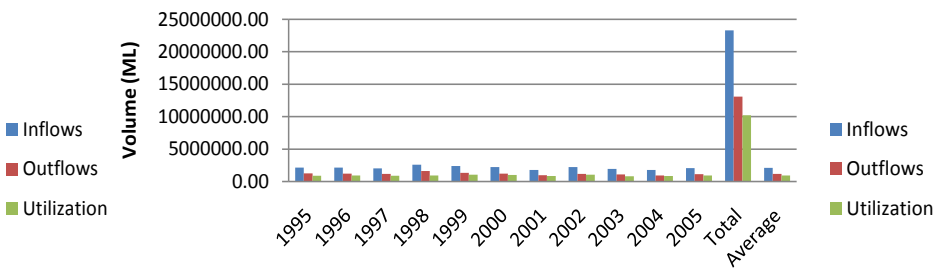

Year

(k)

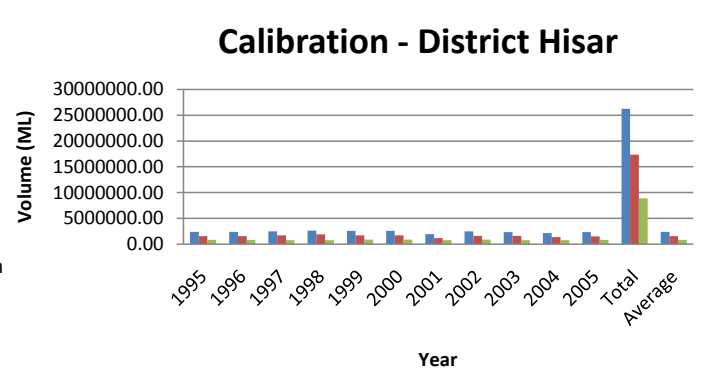

Inflows - Outflows - Utilization

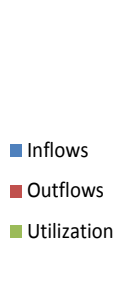

- Outflows - Utilization

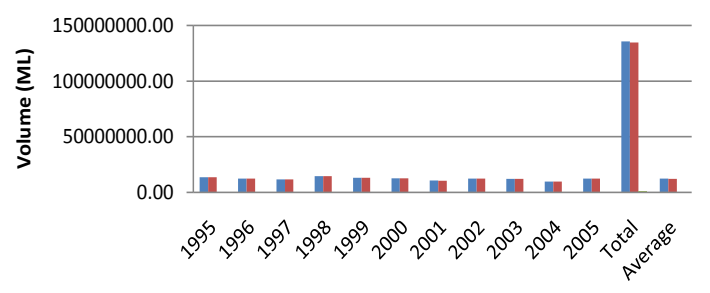

- Inflows - Outflows ntilization

(o)

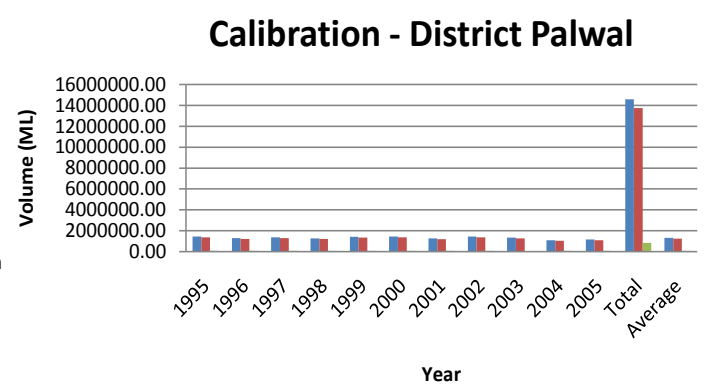

(q)

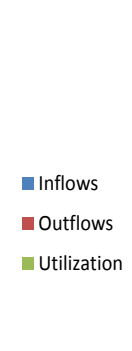

\section{Calibration - District Sirsa}

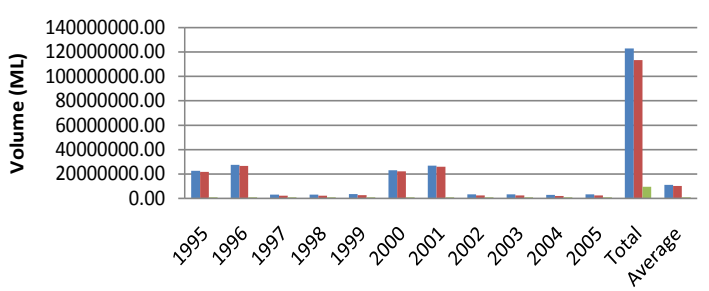

Inflows - Outflows Utilization Year 


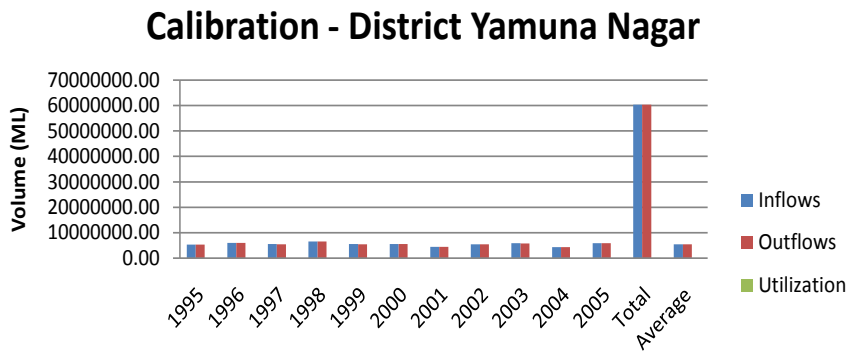

Year

(t)

\section{Calibration Over All Haryana}

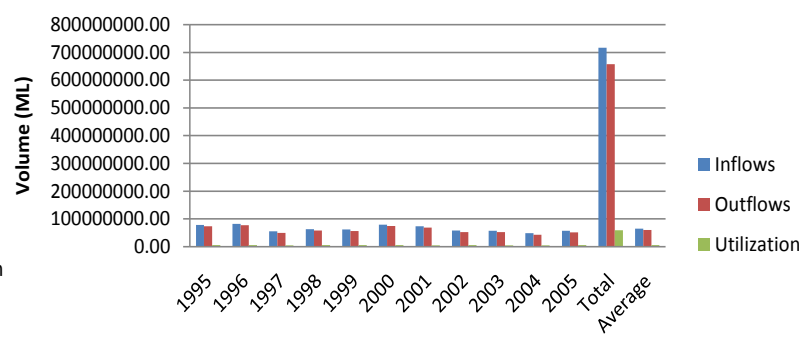

(u)

Figure 5. Water balance of all districts of Haryana (calibration).

\section{Validation -District Ambala}

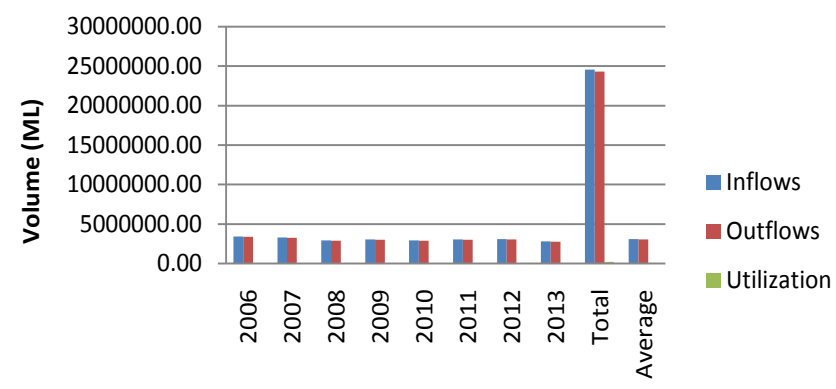

Year

(a)

\section{Validation -District Bhiwani}

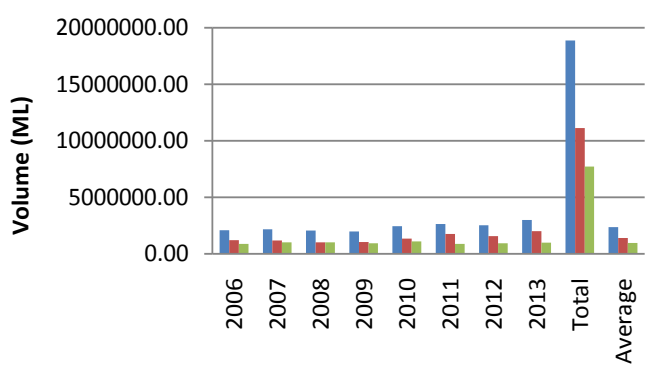

Year

(b)

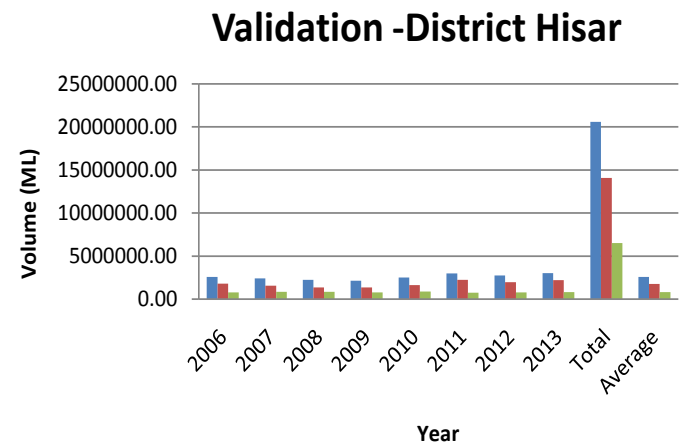

(d)

\section{Validation -District Fatehabad}

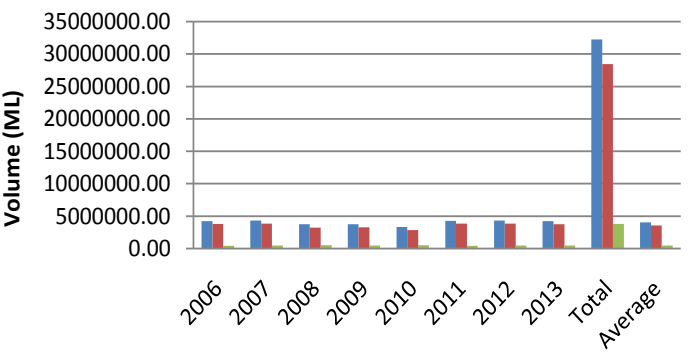

Year

(c)
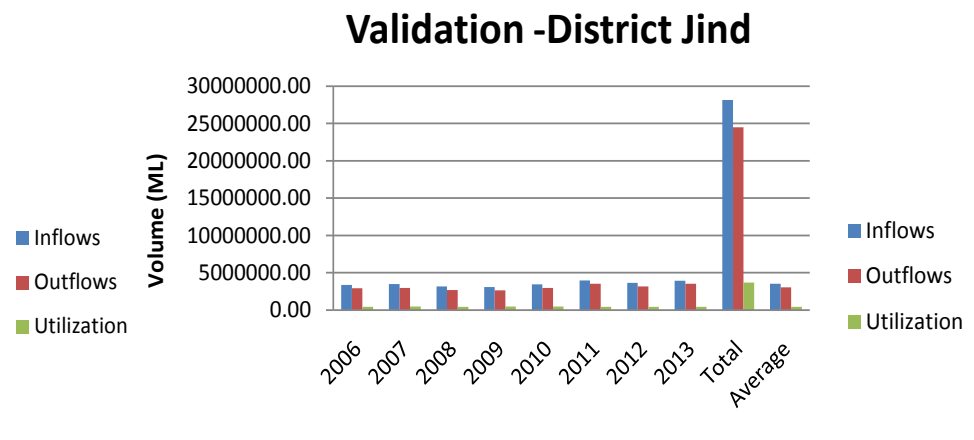

Year

(e) 


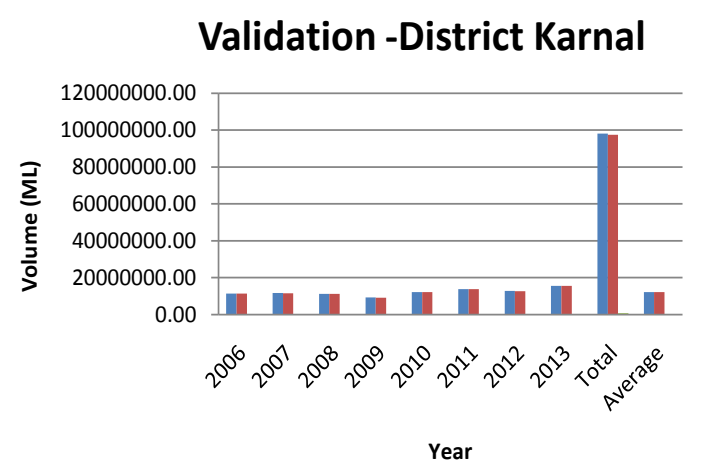

(f)

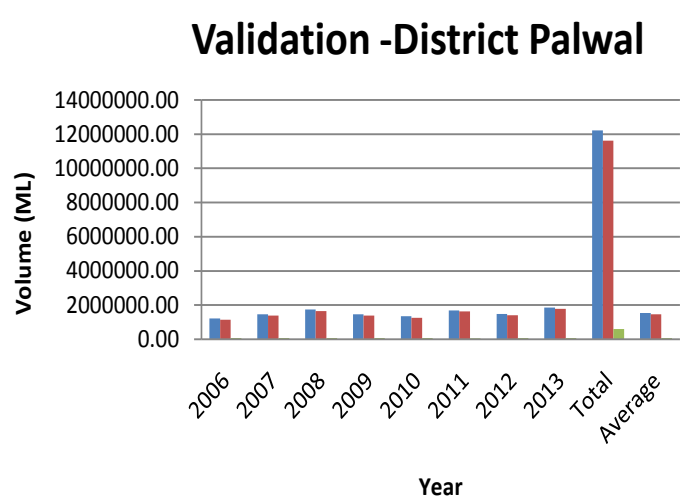

(h)

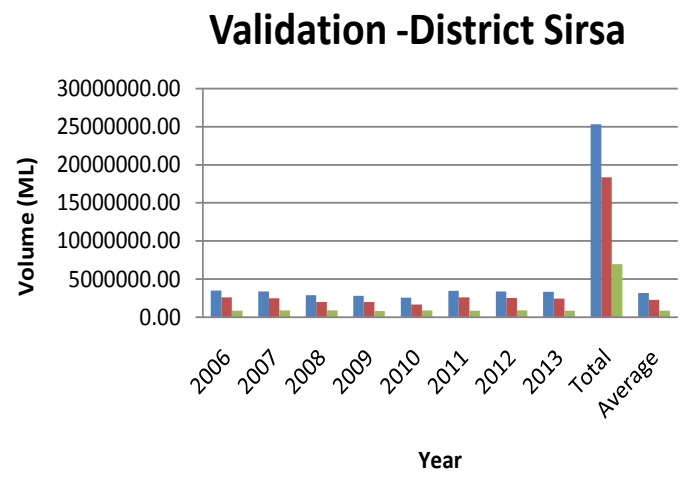

(j)

\section{Validation -District Faridabad}

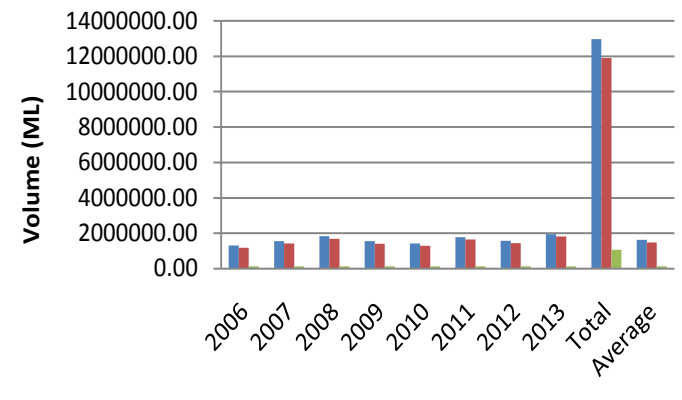

Year

(1)

\section{Validation -District Mahendergarh}

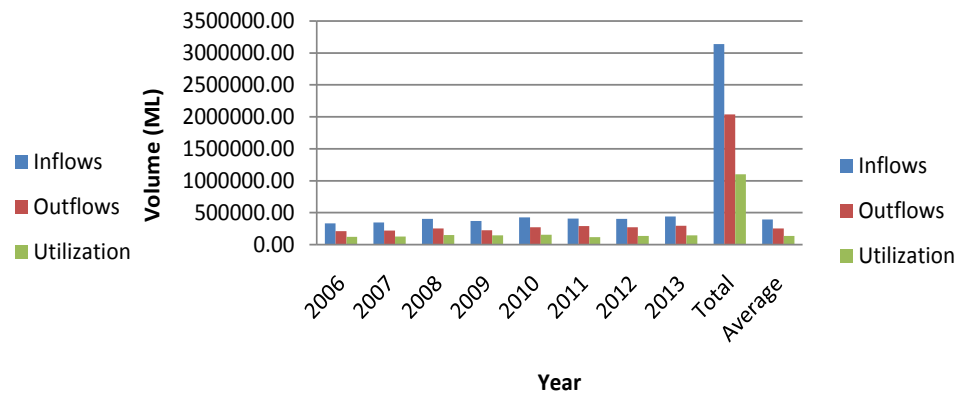

(g)

\section{Validation -District Rewari}
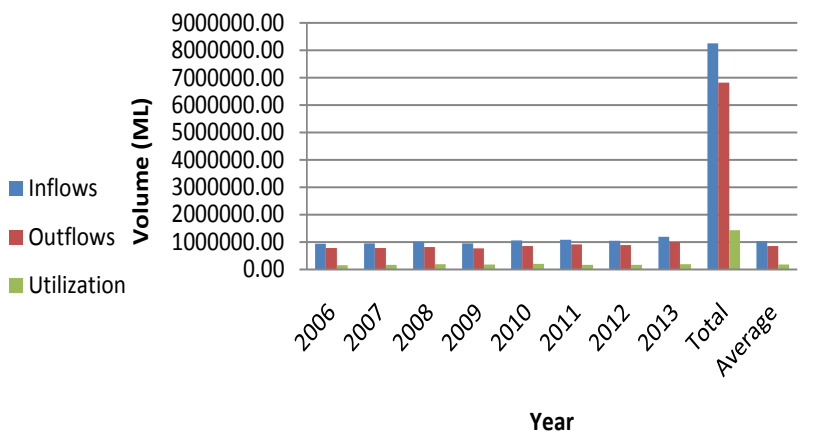

Inflows

- Outflows

Utilization

(i)

\section{Validation -District Yamuna Nagar}

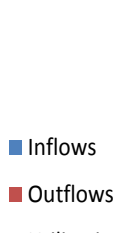

antanation

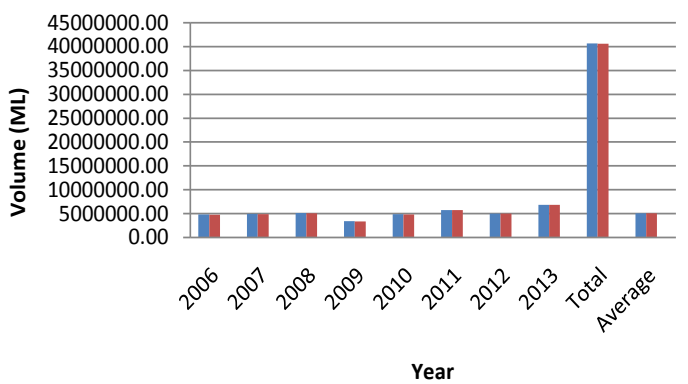

- Inflows

- Outflows

- Utilization

(k)

\section{Validation -District Gurugram}
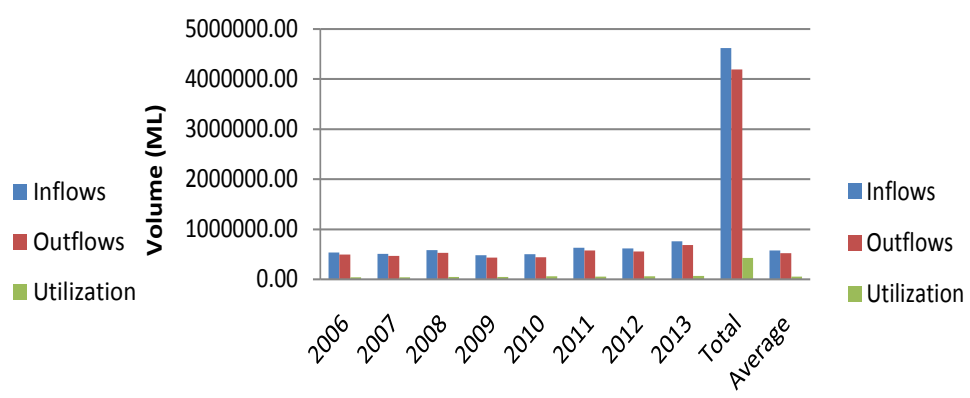

Year

(m) 


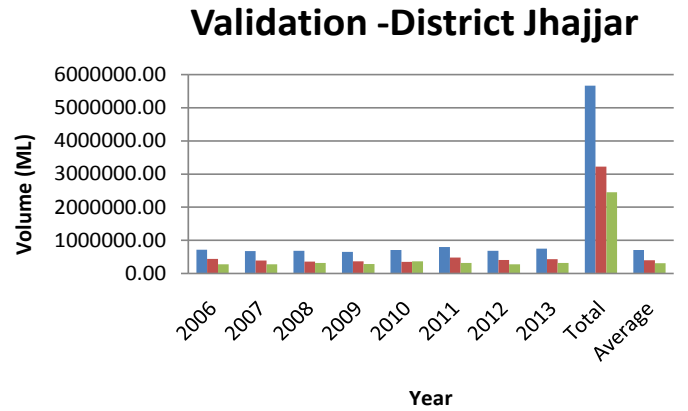

(n)

\section{Validation -District Kurukshetra}

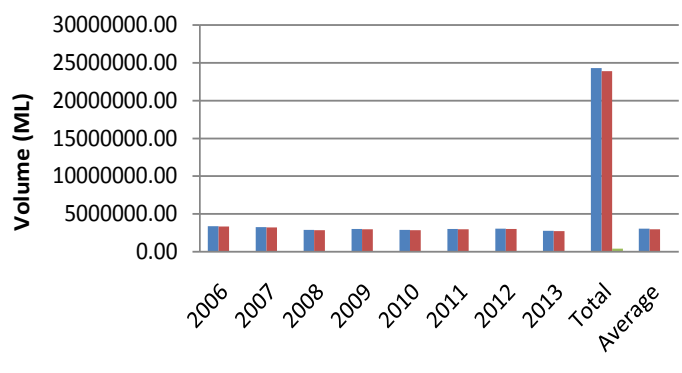

Year

(p)

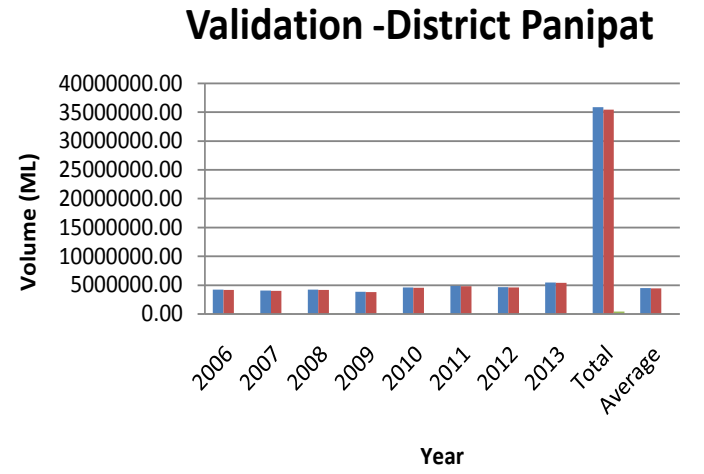

(r)

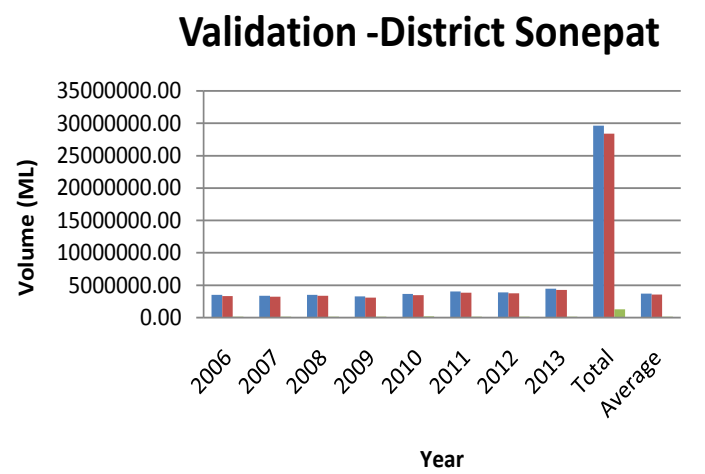

(t)

\section{Validation -District Kaithal}

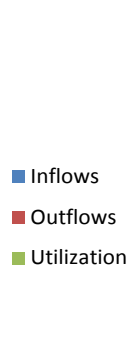

- Inflows

Outflows - Utilization 0.00

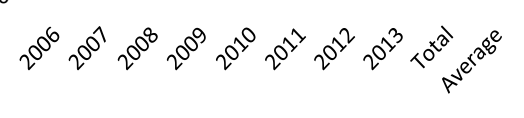

Year

(q)

\section{Validation -District Rohtak}

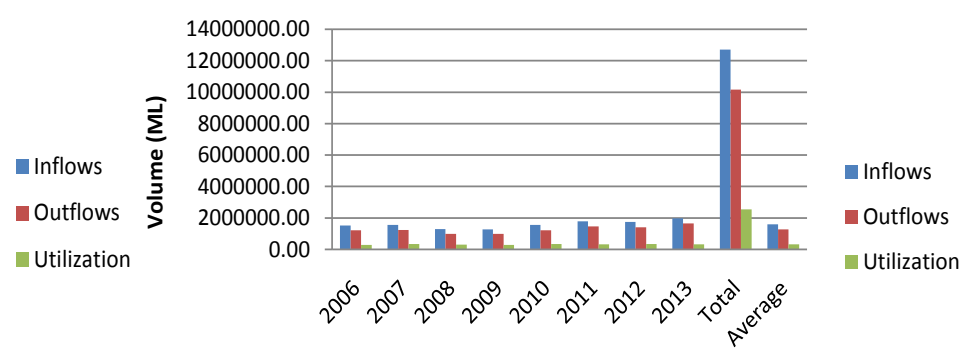

Year

(s)

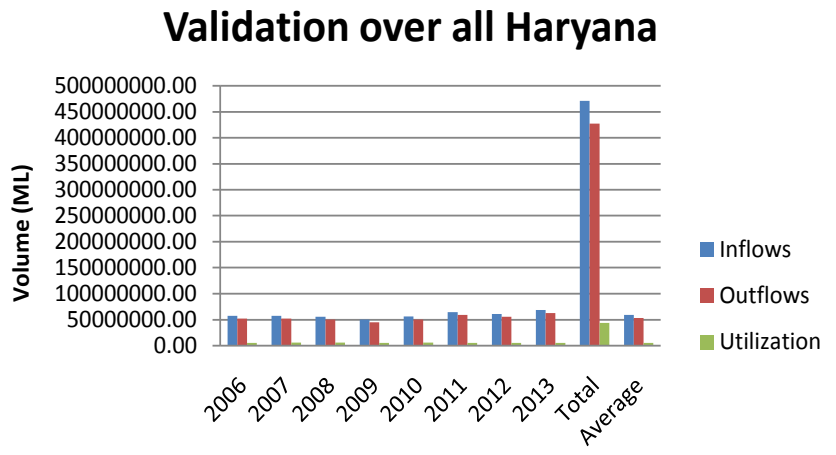

Year

(u)

Figure 6. Water balance of all districts of Haryana (validation). 


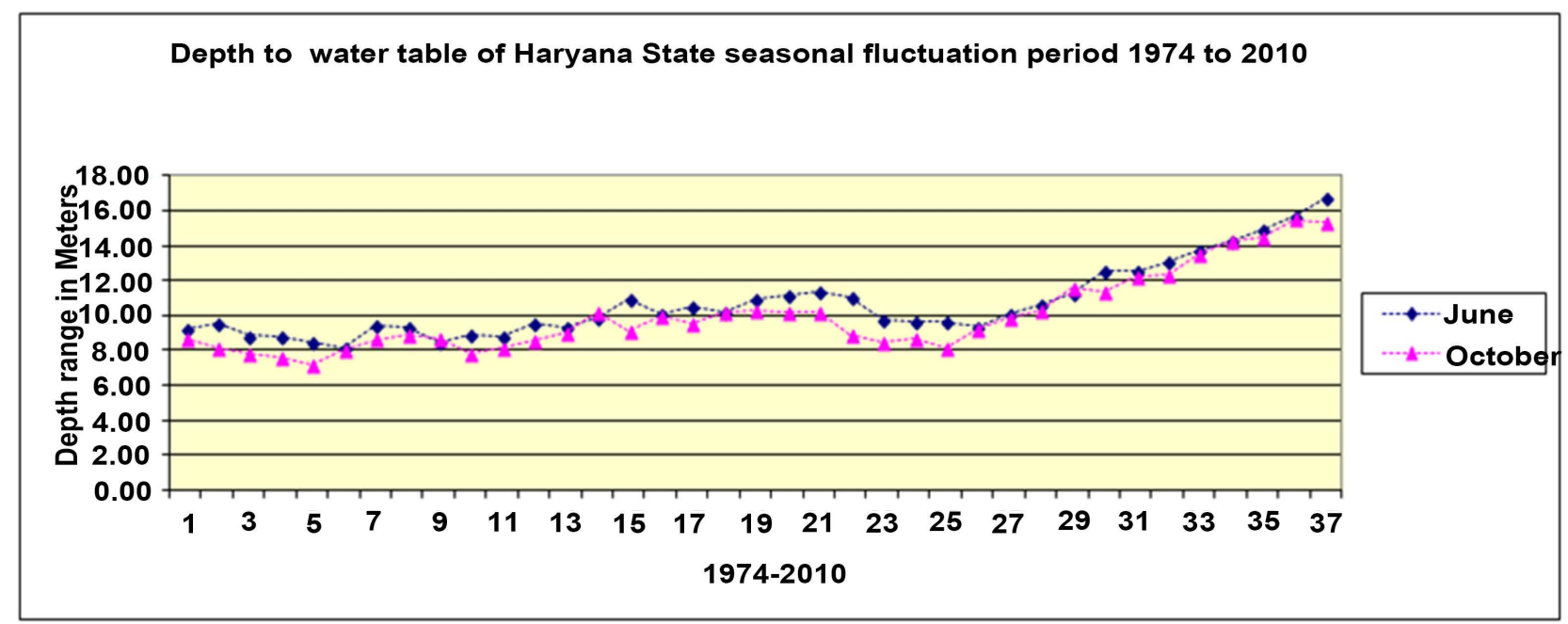

Figure 7. Ground water fluctuation of Haryana state (Year 1974-2010).

The ground water levels of district of Bhiwani, Fatehabad, Gurgaon, Kurukshetra, Kaithal, Mahendergarh and Rewari have gone down more than $20 \mathrm{~m}$ from the year 1974-2010 (Table 5). The maximum extraction of ground water is in Mahendergarh district. The water table was at $16 \mathrm{~m}$ depth in the year 1974, 26 $\mathrm{m}$ in 2001 and increased to $46 \mathrm{~m}$ in the year 2010. Similarly, in the district of Kurukshetra the ground water levels have gone down from 10m in the year 1974 to $29 \mathrm{~m}$ in the year 2010. Gurgaon district also experienced the increase in depth from $6.1 \mathrm{~m}$ to $24 \mathrm{~m}$ in the same period.

For the state of Haryana the overall water levels have gown down from $9 \mathrm{~m}$ in the year 1974 to more than $16 \mathrm{~m}$ in the year 2010 (Table 5). The average state ground water depth varies from $8.18 \mathrm{~m}$ to $11.36 \mathrm{~m}$ in the month of June and from $7.14 \mathrm{~m}$ to $10.29 \mathrm{~m}$ in the month of October for the period 1974 to 2000. But the average state ground water depth has further increased from $10.6 \mathrm{~m}$ to 16.71 $\mathrm{m}$ for June and $10.31 \mathrm{~m}$ to $15.52 \mathrm{~m}$ for October for the year 2001 to 2010 (Table 5). From the above, it is clear that the ground water extraction rate has increased from year to year. It indicates that ground water is being indiscriminately utilized for agriculture and other uses in Haryana. The main reason can be due to non availability of canal water during the period when crop needs water since canals run as per their rotation program. The canal runs for eight days and there is no water for the next 24 days. So the crop demand during this period is met through ground water only. The farmers are also using flood irrigation and this may lead to over exploitation of ground water this mat lead to poor water use efficiencies.

\subsection{Irrigation Water Use Efficiency}

The irrigation water use efficiency has been defined either at root zone level or at conveyance/distribution scale. Here in this study irrigation water use efficiency has been defined at the district level. Hence, all data have been scaled to the 


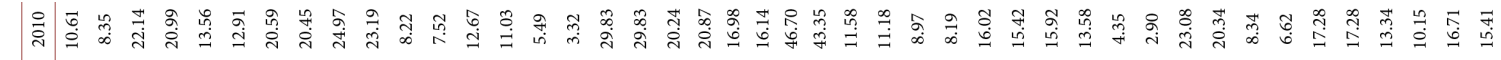

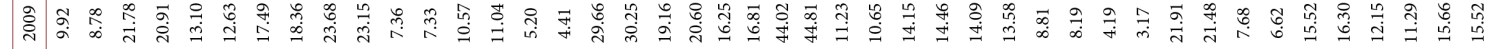

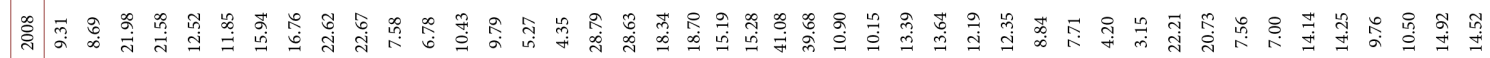

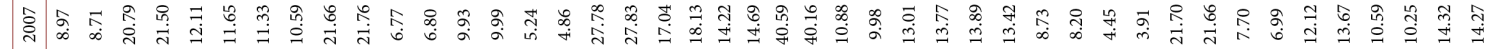

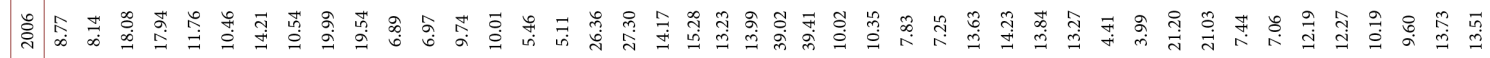

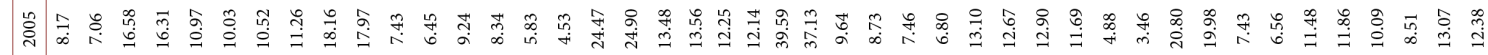

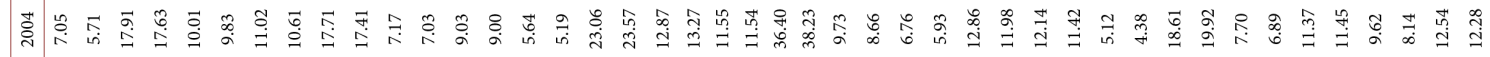

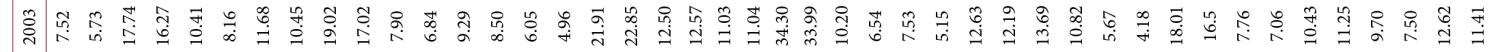

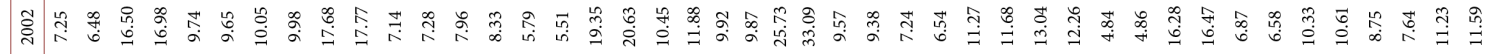

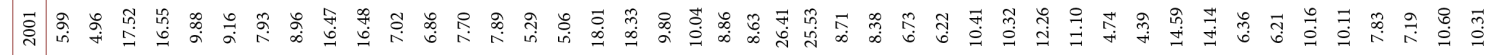

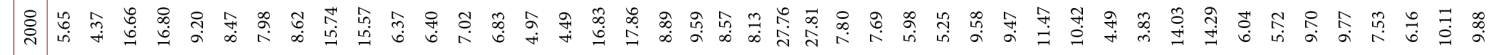

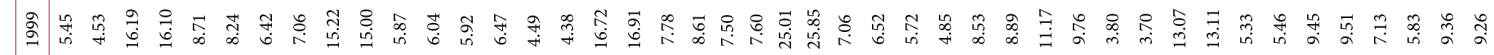

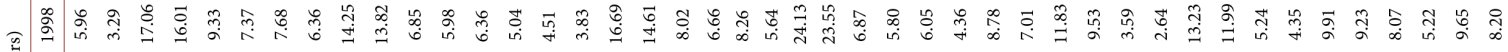

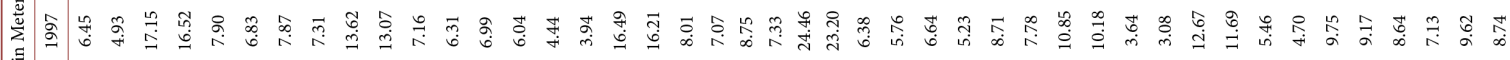

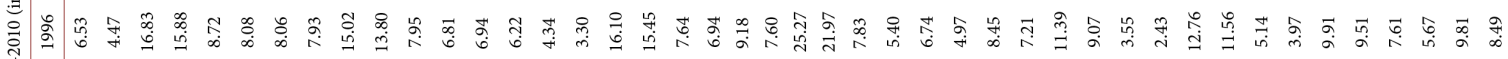

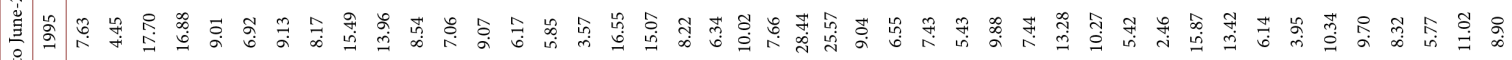

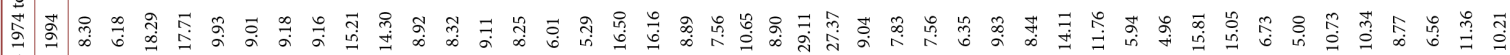

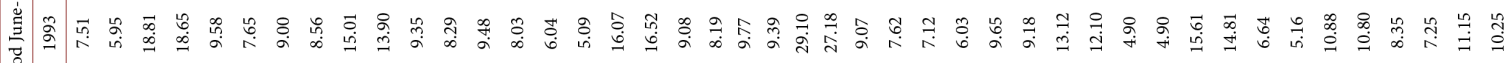

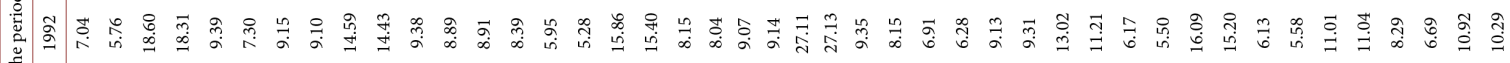

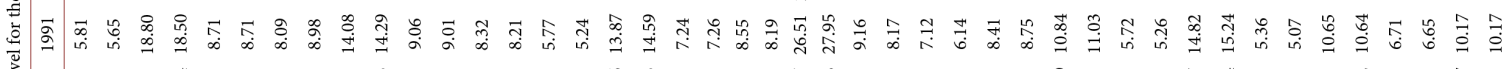

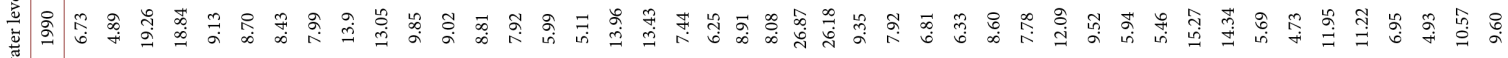

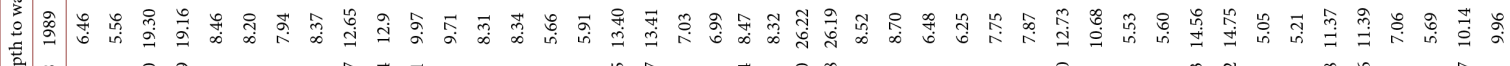

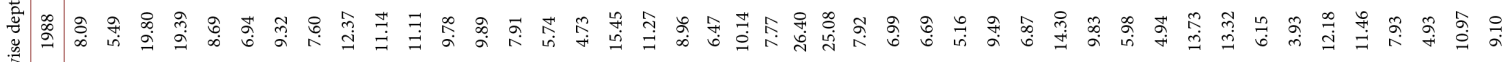

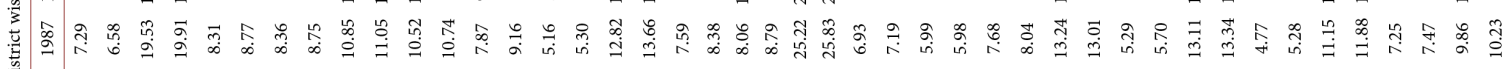

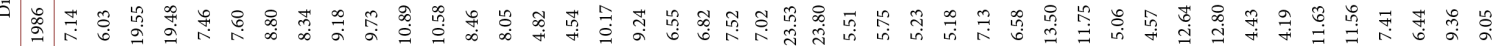

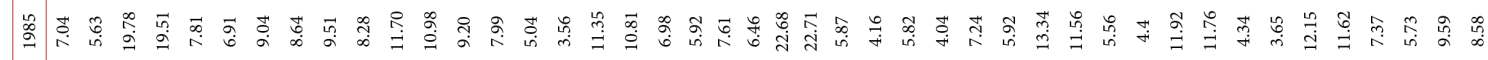

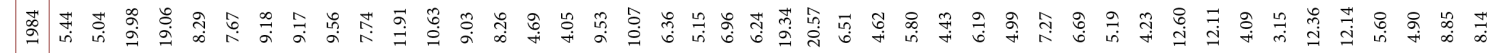

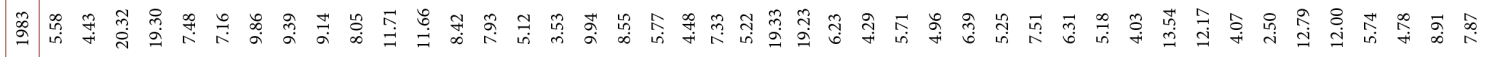

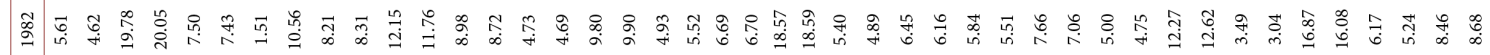

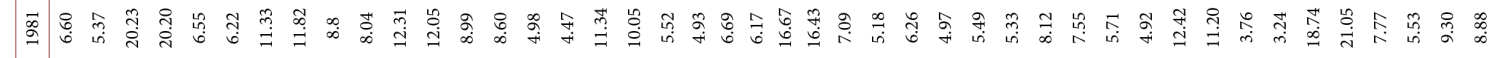

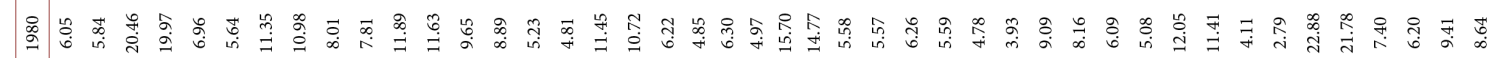

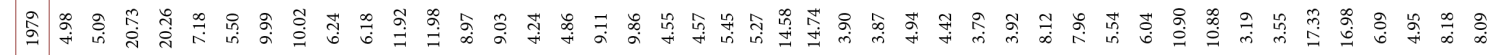

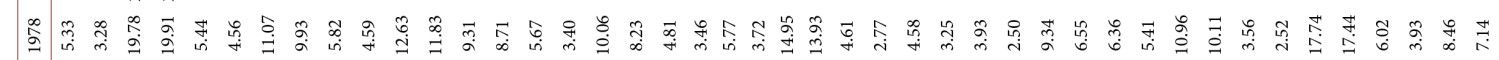

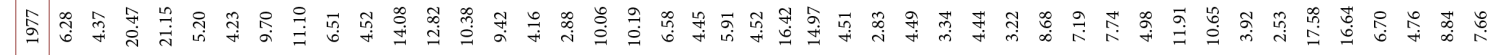

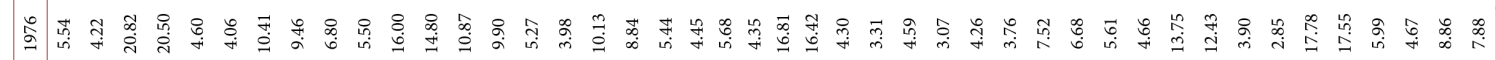

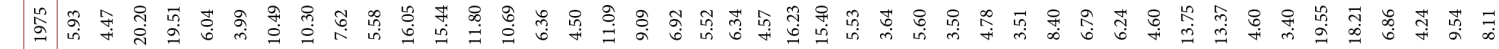

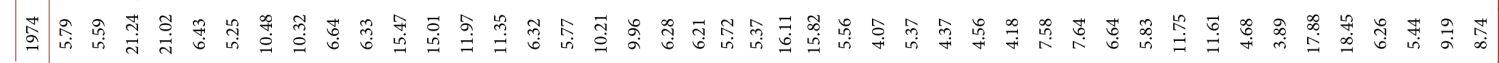

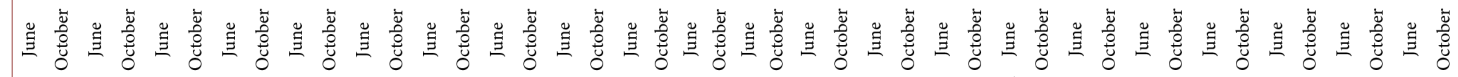

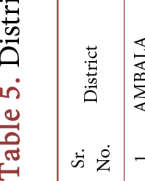

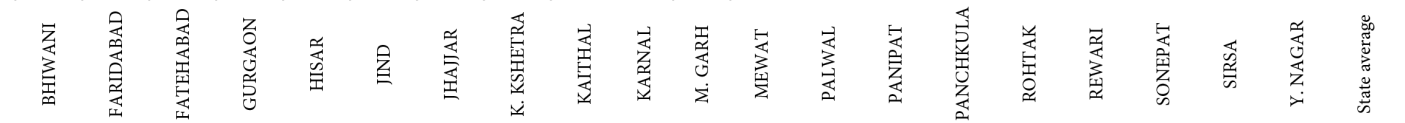


district level to understand the water use efficiency. The quantification of surface irrigation water and groundwater for irrigation has been done at the district level.

The procedure for calculating the water use efficiency for Karnal District is being explained to show how to calculate the water use efficiency of each district. The total geographical area of Karnal district is 2520 square kilometer. Out of this, the gross command and culturable command area of Karnal are 853.3 square kilometer and 707.8 square kilometer respectively. Groundwater is also being extracted for irrigation in Karnal district. Karnal District is being supplied water from five canals: Chautang Feeder, off-takes of WJC-MB, Nardak-Gogripur off-takes of NBK-Link, other off-takes of NBL-link and Goli distributory. Wheat, Gram, Rabi oil seeds, Rice, Bajra, Maize and Sugarcane crops are grown in Karnal district.

The irrigator canal model (crop model) has been run to generate the water requirements to meet the crop water demand. For Karnal district the average water requirement is $765,488.07 \mathrm{ML}$ and the average water utilization or canal irrigation supplies are 85,111.44 ML for the year 2006 to 2010. The average groundwater draft for irrigation for the period 2006 to 2010 is 1,206,470 ML in Karnal district. The period of 2006 to 2010 is taken because ground water draft data is available only for this period.

The WUE at district level is defined as:

$$
\text { WUE }=\left(\frac{\text { Regulated Requirements }}{\text { Canal Irrigation Supplies }+ \text { Ground Water Draft }}\right) * 100
$$

The overall water use efficiency of Karnal district has been worked out to be $59 \%$ (Table 6). This is low value and indicates that excess water is extracted to meet the water demand generated by water user nodes in Karnal district.

Similarly, water use efficiency of other districts has also been calculated. The water use efficiency of all the districts is shown in Table 6. It is found that the water use efficiency of all the districts of Haryana varies from lowest value of $27 \%$ for Mewat district to highest value of 59\% for Karnal district. The overall water use efficiency of Haryana state is poor and its value is $39 \%$. Hence, there is scope for improving the WUE for the State of Haryana.

\subsection{Validation at Mathura}

The model has been validated at Mathura, the outlet of the study area. The validation period is from January 1, 1996 to May 31, 2006 as CWC data is available only up to that period. The value of the objective function NSE Daily \& $\log$ Flow duration comes out to be 0.54 . Though the value of the objective function is low at the outlet of the study area as compared to the values of the objective function in upstream Gauges in hilly areas but the model has been properly calibrated and validated at other sites. The model overestimates peaks at certain periods but overall the model predicts good results Figure 8 . 
Table 6. District wise water use efficiency.

\begin{tabular}{|c|c|c|c|c|}
\hline District & Water Requirements (ML) & $\begin{array}{c}\text { Canal Irrigation Supplies } \\
\text { (ML) }\end{array}$ & $\begin{array}{c}\text { Ground Water } \\
\text { Irrigation draft }(\mathrm{ML})\end{array}$ & WUE (\%) \\
\hline Ambala & $126,281.75$ & $32,332.40$ & 382,330 & 30 \\
\hline Bhiwani & $720,616.63$ & $983,233.80$ & 705,960 & 43 \\
\hline Faridabad & $93,453.36$ & $136,338.90$ & 126,910 & 35 \\
\hline Fatehabad & $632,453.52$ & $483,670.38$ & 906,600 & 45 \\
\hline Gurgaon & $115,764.65$ & $48,335.58$ & 362,660 & 28 \\
\hline Hisar & $771,289.27$ & $827,242.22$ & 578,410 & 55 \\
\hline Jhajjar & $211,882.22$ & $306,193.08$ & 407,680 & 30 \\
\hline Jind & $479,262.18$ & $468,299.12$ & 910,790 & 35 \\
\hline Kaithal & $512,730.05$ & $309,185.04$ & $1,083,160$ & 37 \\
\hline Karnal & $765,488.07$ & $85,111.44$ & $1,206,470$ & 59 \\
\hline Kurukshetra & $293,384.09$ & $52,592.72$ & 710,990 & 38 \\
\hline Mahendergarh & $107,982.52$ & $140,738.48$ & 225,060 & 30 \\
\hline Mewat & $56,325.70$ & $34,124.27$ & 175,860 & 27 \\
\hline Palwal & $157,072.84$ & $76,899.48$ & 405,970 & 33 \\
\hline Panipat & $186,618.88$ & $56,090.61$ & 501,480 & 33 \\
\hline Rewari & $155,613.46$ & $180,849.32$ & 319,990 & 31 \\
\hline Rohtak & $329,116.09$ & $312,416.04$ & 304,880 & 53 \\
\hline Sirsa & $1,283,365.73$ & $870,369.90$ & $1,354,430$ & 58 \\
\hline Sonipat & $415,178.20$ & $154,999.52$ & $1,026,170$ & 35 \\
\hline Yamunanagar & $242,184.53$ & 8038.10 & 564,340 & 42 \\
\hline Total & $7,656,063.76$ & $5,567,060.39$ & $12,260,140$ & \\
\hline Average & $382,803.19$ & $278,353.02$ & 613,007 & 39 \\
\hline
\end{tabular}

Gauge: Mathura: Downstream Flow

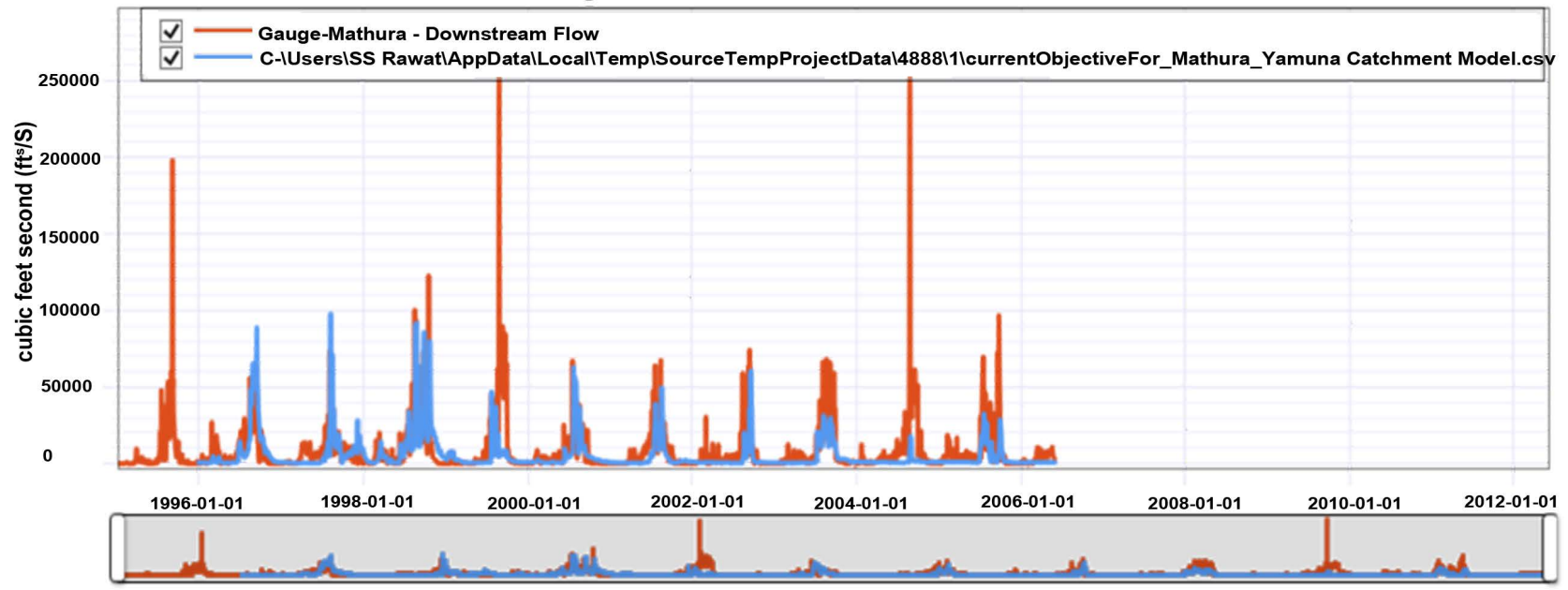

Figure 8. Validation at Mathura, the outlet of study area. 


\section{Conclusions}

In the paper a detailed study of hydrological models and irrigator canal model has been made to evaluate flows at different sites, water balance and water use efficiency at the district level. An integrated model of the state of Haryana and Yamuna catchment contributing flows in Haryana has been conceptualized. GR4J, GR4JSG and Irrigator models have been successfully applied to evaluate the modeled stream flow. The evaluation with observed stream flow was done using NSE daily and Log flow duration. The model calibration and validation are based on split-sample.

The study has been successful in achieving the objectives of water balance and water use efficiency at district level for proper planning of water resources. The water use efficiency has been worked out to be low for Haryana under the case as usual. It is suggested to application of micro irrigation techniques such as drip and sprinkler irrigation. The water thus saved can further be utilized for increasing low flows in Yamuna downstream of HKB/Tajewala.

\section{References}

[1] Tahal (2001) Development of Haryana State Water Plan. Tahal Consulting Engineers Ltd., Tel Aviv.

[2] WAPCOS (2003) Pilot Project Study on Water Use Efficiency of Western Yamuna Canal. Planning Commission, Government of India, Haryana.

[3] Kumar, V. and Goel, M.K. (2007) System Simulation Study for Development of Optimal Allocation Plan for Ground and Surface Water in Parts of Western Yamuna Canal Command Area in the State of Haryana, Roorkee. National Institute of Hydrology, Roorkee and Central Ground Water Board, Faridabad.

[4] Aggarwal, K.C., Kumar, V. and Dass, T. (1983) Snowmelt Runoff for a Catchment of Beas Basin. Proceedings of the 1 st National Symposium on Seasonal Snowcover, Manali, Vol. 2, 43-63.

[5] Nepal, S., Chen, J., Penton, D.J., Neumann, L.E., Zheng, H. and Wahid, S. (2016) Spatial GR4J Conceptualization of the Tamor Glaciated Alpine Catchment in Eastern Nepal: Evaluation of GR4JSG against Steamflow and MODIS Snow Extent. $\mathrm{Hy}$ drological Processes, 31, 51-68. https://doi.org/10.1002/hyp.10962

[6] Perrin, C., Michael, C. and Andreassian, V. (2003) Improvement of a Parsimonious Model for Stream Flow Simulations. Journal of Hydrology, 279, 275-289. https://doi.org/10.1016/S0022-1694(03)00225-7

[7] Hock, R. (2003) Temperature Index Melt Modelling in Mountain Areas. Journal of Hydrology, 282, 104-115. https://doi.org/10.1016/S0022-1694(03)00257-9

[8] Welsh, W.D., Vaze, J., Datta, D., Rassam, D., Rehman, J.M., Jolly, I.D. and Lerat, J. (2013) An Integrated Modelling Framework for Regulated River Systems. Environmental Modelling \& Software, 39, 81-102. https://doi.org/10.1016/j.envsoft.2012.02.022

[9] eWater Source (2012) Australia's National Hydrological Modelling Platform (NHMP), ACT. eWater Solutions, Canberra.

[10] Allen, R.G., Pereira, L.S., Raes, D. and Martin, S. (1998) Crop Evapotranspiration-Guidelines for Computing Crop Water Requirements. FAO Irrigation and Drainage Paper 56, FAO, Rome. 
[11] Kelley, P. and O’Brien, A. (2012) Source Scientific Reference Guide. eWater Cooperative Research Centre, Canberra.

[12] Delgado, P., Kelley, P., Murray, N. and Satheesh, A. (2012) Source User Guide. eWater Cooperative Research Centre, Canberra.

[13] Argent, R.M., Perruad, J.M., Grayson, R.B. and Podger, G.M. (2009) A New Approach to Water Quality Modeling and Environmental Decision Support Systems. Environmental Modeling and Software, 24, 809-818.

https://doi.org/10.1016/j.envsoft.2008.12.010

[14] Panday, P.K., Williams, C.A., Frey, K.E. and Brown, M.E. (2013) Application and Evaluation of a Snowmelt Runoff Model in the Tamor River Basin, Eastern Himalaya using a Markov Chain Monte Carlo (MCMC) Data Assimiliation Approach. Hydrological Processes, 28, 5337-5353. https://doi.org/10.1002/hyp.10005

[15] Nepal, S., Krause, P., Flugel, W.A., Fink, M. and Fischer, C. (2014) Understanding the Hydrological System Dynamics of a Glaciated Alpine Catchment in the Himalayan Region using the J2000 Hydrological Model. Hydrological Processes, 28, 1329-1344. https://doi.org/10.1002/hyp.9627

[16] Prasad, V.H. and Roy, P.S. (2005) Estimation of Snowmelt Runoff in Beas Basin, India. Geocarto International, 20, 41-47. https://doi.org/10.1080/10106040508542344

[17] Thakur, P.K. (2014) Snow Melt Runoff Status in Part of Ganga Basin. 241-260. https://doi.org/10.1007/978-3-319-00530-0_10

[18] Nepal, S. (2012) Evaluating Upstream-Downstream Linkages of Hydrological Dynamics in the Himalayan Region, Jena. PhD Thesis, Frieddrich Schiller Universty of Jena, Jena.

[19] Nash, J.E. and Sutcliffe, J.V. (1970) River Flow Forecasting through Conceptual Models Part 1-A Discussion of Principles. Journal of Hydrology, 10, 282-290. https://doi.org/10.1016/0022-1694(70)90255-6 